\title{
Biostratigraphy and evolution of Miocene Discoaster spp. from IODP Site U1338 in the equatorial Pacific Ocean
}

\author{
Marina Ciummelli ${ }^{*}$, Isabella Raffi² ${ }^{2}$ Jan Backman ${ }^{3}$ \\ ${ }^{1}$ PetroStrat Ltd, Tan-y-Graig, Parc Caer Seion, Conwy LL32 8FA, UK \\ 2 Dipartimento di Ingegneria e Geologia, Università 'G. d'Annunzio' di Chieti-Pescara, I-66013 Chieti Scalo, Italy \\ ${ }^{3}$ Department of Geological Sciences, Stockholm University, SE-106 91 Stockholm, Sweden \\ *Correspondence: marina.ciummelli@petrostrat.com
}

\begin{abstract}
Assemblages of upper lower through upper Miocene Discoaster spp. have been quantified from Integrated Ocean Drilling Program (IODP) Site U1338 in the eastern equatorial Pacific Ocean. These assemblages can be grouped into five broad morphological categories: six-rayed with bifurcated ray tips, six-rayed with large central areas, six-rayed with pointed ray tips, five-rayed with bifurcated ray tips and five-rayed with pointed ray tips. Discoaster deflandrei dominates the assemblages prior to $15.8 \mathrm{Ma}$. The decline in abundance of $D$. deflandrei close to the early-middle Miocene boundary occurs together with the evolution of the $D$. variabilis group, including $D$. signus and D. exilis. Six-rayed discoasters having large central areas become a prominent member of the assemblages for a $400 \mathrm{ka}$ interval in the late middle Miocene. Five- and six-rayed forms having pointed tips become prominent in the early late Miocene and show a strong antiphasing relationship with the $D$. variabilis group. Discoaster bellus completely dominates the Discoaster assemblages for a $400 \mathrm{ka}$ interval in the middle late Miocene. Abundances of all discoasters, or discoasters at the species level, show only (surprisingly) weak correlations to carbonate contents or oxygen and carbon isotopes of bulk sediment when calculated over the entire sample interval.
\end{abstract}

Keywords: Miocene, Discoaster spp., equatorial Pacific, five major morphogroups, abundance variations

Received 4 December 2015; accepted 18 April 2016

Miocene times were characterized by major changes in ocean circulation and global climate that were driven by a complex set of factors operating on tectonic, orbital and suborbital time scales (Zachos et al. 2001). This time-dependent development of Miocene palaeoenvironmental conditions is reflected in the distribution and evolutionary patterns, often expressed in terms of biostratigraphic resolution, among the dominant sediment-forming oceanic plankton groups (Kennett \& Srinivasan 1983; Perch-Nielsen 1985; Baldauf \& Barron 1990). In a review of Miocene through Pleistocene open-ocean calcareous nannofossil evolutionary appearances and extinctions, Raffi et al. (2006) show eight biochronologically useful biohorizons between 23 and 14 Ma, giving an average rate of 1.5 biohorizons per million years. In the next following eight million years $(14-6 \mathrm{Ma})$, the number of biohorizons are 29 (3.6 biohorizons/million years), representing well over a doubling of the rate of taxonomic evolution among open-ocean calcareous nannofossils compared with that of the early half of the Miocene. Nearly half (14 of 29) of Raffi's biohorizons in the younger half of the Miocene are represented by members of the genus Discoaster. This key group (genus) among Cenozoic calcareous nannofossils thus demonstrates a distinct evolutionary response to changing conditions in the photic zone of the middle and late Miocene oceans, if assuming that discoasters belonged to the Haptophytes, a specific group of unicellular photosynthetic protists. This assumption is supported by the group's environmental distribution (marine), its abundance (a dominant component of finegrained low to middle latitude carbonate sediments over a $c .55 \mathrm{Ma}$ long time interval [note that we follow Holden et al. (2011) in referring to both absolute age and time durations as $\mathrm{Ma}$, in order to achieve 'compliance with the international standard']), size range $(4-30 \mu \mathrm{m})$, mineralogy (low magnesium calcite) and obvious biological origin. However, fossil Discoaster-bearing coccospheres have never been observed.
Discoasters are considered to thrive in warmer waters (Edwards 1968; Perch-Nielsen 1972; Bukry 1973a; Haq \& Lohmann 1976), although Wei \& Wise (1990) pointed out that there is no simple linear relationship between Discoaster abundance and water temperature. Discoasters have been suggested to thrive also under oligotrophic conditions (Chepstow-Lusty et al. 1989, 1992; Gibbs et al. 2004). This makes the Eastern Equatorial Pacific (EEP) an interesting place for the study of Miocene discoasters, as this region offers equatorial temperatures combined with high nutrient availability and productivity conditions in the photic zone via wind-driven upwelling (Pennington et al. 2006). This upwelling system in the EEP appears to have been operational for tens of millions of years (Moore et al. 2004).

Higher-resolution stratigraphic studies of Neogene calcareous nannofossils from this environmental setting in the EEP have demonstrated that the distribution of Neogene Discoaster taxa exhibits rapid fluctuations in abundance, or even discontinuous occurrences over short stratigraphic intervals (Raffi \& Flores 1995; Raffi et al. 1995; Backman et al. 2013). Furthermore, discoasters are considered to be among the least dissolution-susceptible calcareous nannofossils (Bukry 1971a, 1973a; Roth \& Thierstein 1972; Lohmann \& Carlson 1981).

The abundance fluctuations, or absence, of discoasters in Neogene carbonate sediments of the EEP are here, therefore, assumed to mainly reflect variable conditions in the sunlit uppermost part of the water column, in which some set of conditions promoted and some other set of conditions suppressed the productivity of discoasters.

Abundance data of Discoaster assemblages in Miocene sediments have been generated from IODP Site U1338, located in the $\mathrm{EEP}$ at $2^{\circ} 30.469^{\prime} \mathrm{N}, 117^{\circ} 58.174^{\prime} \mathrm{W}$ at a water depth of $4210 \mathrm{~m}$ (Pälike et al. 2010). This Miocene sediment sequence at Site U1338 may be considered to reflect variations in photic zone conditions 
and Discoaster productivity during its plate tectonic travel from a position $c .76 \mathrm{~km}$ south of the Equator at $17-18 \mathrm{Ma}$ to its present location c. $278 \mathrm{~km}$ north of the Equator. The Equator crossing occurred at about $10 \mathrm{Ma}$ (Pälike et al. 2010).

A key aim of the present study is to investigate abundance variations, evolutionary trends and biostratigraphic properties among upper lower Miocene through upper Miocene members of the genus Discoaster at IODP Site U1338. Moreover, we investigate possible correlations between Discoaster abundance fluctuations and palaeoenvironmental conditions in the mixed layer (photic zone).

\section{Material and methods}

The composition of Site U1338 sediments changes from chalks in the upper lower Miocene sequence to oozes in the upper Miocene, with frequent and rapid changes in the proportions between calcareous and biosiliceous components. Non-biogenic components are consistently $<5 \%$ (Pälike et al. 2010).

The interval examined represents a continuous $336 \mathrm{~m}$ thick, spliced sequence from three holes of upper lower through uppermost Miocene sediment between 406 and 72 m CCCSF-A. This depth scale refers to metres compressed composite depth. For Site U1338, this scale corresponds to the CCSF-A depth, or metres composite depth in the splice of the three holes drilled at this site, divided by a factor of 1.107 (Pälike et al. 2010). Their shipboard splice was subsequently revised by Wilkens et al. (2013). This revised splice of Site U1338 is used here, and all depths given below and in plots refer to the revised CCSF-A depth scale of Wilkens et al. (2013), divided by 1.107; this compressed CCSF-A scale is referred to as CCSF-B (=CCCSF-A) by Pälike et al. (2010, Site U1338, p. 29). Furthermore, depths of Discoaster locations are given as mid-points between nearest samples, for example, the base of Discoaster bellus occurs between $225.14 \mathrm{~m}$ and $225.87 \mathrm{~m}$, giving a mid-point at $225.51 \mathrm{~m}$.

The investigated $336 \mathrm{~m}$ thick sediment sequence represents the time interval between $c .17 .8$ and $5.3 \mathrm{Ma}$, resulting in an average sedimentation rate of c. $27 \mathrm{~m} \mathrm{Ma}^{-1}$. All age estimates refer to the time scale of Lourens et al. (2004).

Magnetostratigraphy exists in two shorter intervals, from 9.098 Ma (top C4Ar.1r) to $9.987 \mathrm{Ma}$ (top C5n.2n), and $12.730 \mathrm{Ma}$ (top C5Ar.1n) to $15.160 \mathrm{Ma}$ (top C5Br), respectively. These two intervals with magnetostratigraphy together encompass $<27 \%$ of the investigated time interval, implying that age information in the remaining $73 \%$ relies on biochronological interpretation of biostratigraphic data. Sedimentation rates based on biochronology commonly imply interpolation between widely separated biohorizons. We have, therefore, chosen to present the abundance data v. depth rather than age, as age estimates inevitably will change when an improved age model based on astronomical tuning of various sediment properties becomes established. However, when summarizing relative abundances of the major Discoaster groups, we have placed these data on a low-resolution age model for Site U1338 (Backman et al. 2016), using a combination of seven biomagnetostratigraphic indicators from $5.04 \mathrm{Ma} / 68.63 \mathrm{~m}$ to $17.74 \mathrm{Ma} / 406.43 \mathrm{~m}$.

The 494 smear-slides were prepared following the technique of Bown \& Young (1998).

Sample distances vary along the studied interval, with an average depth resolution of one (1) sample every $68 \mathrm{~cm}$. Smear-slides were analysed using a light microscope at $1250 \times$ magnification. Abundance data were obtained by counting the relative abundance of Discoaster species relative to the total number of discoasters, expressed as a percentage, and the number of specimens in a prefixed area on the smear-slide (number of specimens per $\mathrm{mm}^{2}$ ), following Backman \& Shackleton (1983). The calcareous nannofossil biozonation by Backman et al. (2012) was employed.
Morphometric analyses were performed using the image analysis software Image-Pro Plus 6.2. The Discoaster data presented here are from an unpublished $\mathrm{PhD}$ thesis (Ciummelli, M. 2013. Morphometry, evolution, biostratigraphy and ecology of the genus Discoaster in the Miocene using material from Site U1338, IODP Exp. 321. Universita' degli Studi 'G. d'Anninzio', ChietiPescara, 1 - 129).

Author citations for Discoaster species discussed below are to be found in Aubry (1984) and Perch-Nielsen (1985).

\section{Taxonomy and abundance behaviour of five major groups of Miocene discoasters at IODP Site U1338}

Discoaster assemblages evolved rapidly during late early through late Miocene times, resulting in a series of biohorizons that have proved useful in marine biostratigraphy. Robust morphotypes with broad rays were dominant during the early Miocene. These were successively replaced with more slender, thinner-rayed morphotypes during the middle Miocene, an evolutionary trend that Bukry (1971b) considered to reflect the cooling of the Cenozoic oceans. Following the middle Miocene, discoasters stayed thin-rayed until their extinction at the base of the Olduvai subchron (Backman \& Pestiaux 1987). The mutual extinction of the two final Discoaster morphotypes, one with six slender rays (D. brouweri) and a threerayed variety (D. triradiatus), was first recognized by Takayama (1969), who referred to the latter as '3-rayed D. brouweri'.

The Site U1338 Miocene discoasters that are confidently referred to the species level can be brought together into five broad morphological categories based on ray numbers, ray terminations and central area size:

(1) six-rayed morphotypes with bifurcated ray tips;

(2) six-rayed morphotypes with large central areas;

(3) six-rayed morphotypes with pointed ray tips;

(4) five-rayed morphotypes with bifurcated ray tips;

(5) five-rayed morphotypes with pointed ray tips.

\section{Six-rayed morphotypes with bifurcated ray tips}

A group of six-rayed discoasters with bifurcated ray tips includes both thicker- and thinner-rayed morphotypes (Fig. 1:1-1:20). A robust structure with thicker-rayed morphotypes characterizes the following species: D. deflandrei, D. aulakos, D. divaricatus, $D$. woodringi and $D$. icarus. These are hereafter informally referred to as the $D$. deflandrei group (Fig. 1:1-1:5, 1:12). A more slender ray structure characterizes $D$. variabilis, $D$. exilis, $D$. cf. exilis, $D$. signus, $D$. cf. signus, $D$. cf. bollii, D. surculus and $D$. loeblichii. These are hereafter informally referred to as the $D$. variabilis group (Fig. 1:6-1:11, 1:14-1:16). Forms with intergrading morphologies between $D$. variabilis and $D$. exilis on the one hand, and $D$. variabilis and $D$. icarus on the other, are also included in the D. variabilis group.

\section{The Discoaster deflandrei group}

The species included in this group are characterized by six thick bifurcated rays that radiate symmetrically from a well-developed central area. The angle between the bifurcations varies, and so do their shape, from angular to rounded. These characters have been used to distinguish similar-looking species (Gartner 1967; Hay et al. 1967; Aubry 1984).

Two additional species have been referred to the $D$. deflandrei group, namely D. saundersi (Hay et al. 1967) and D. tinquarensis (Furrazzola-Bermùdez \& Itturalde 1967). In this study, only D. aulakos, D. divaricatus and D. woodringi were observed (Fig. 1:3-1:5). The latter species was described by Bramlette \& Riedel (1954) and has been considered to represent an artificial species 

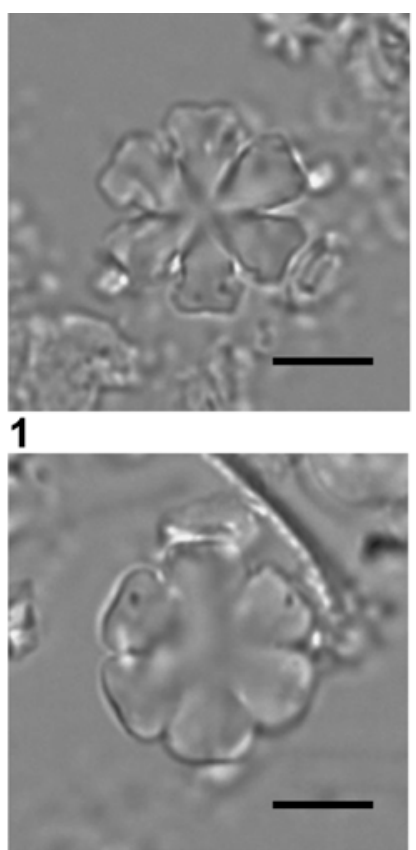

5

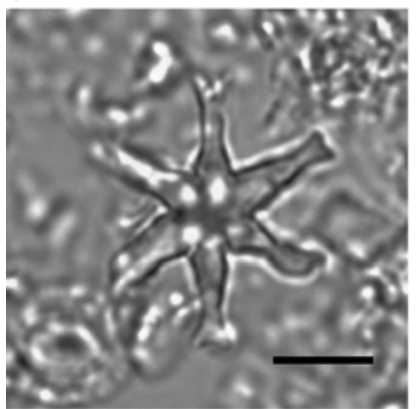

9

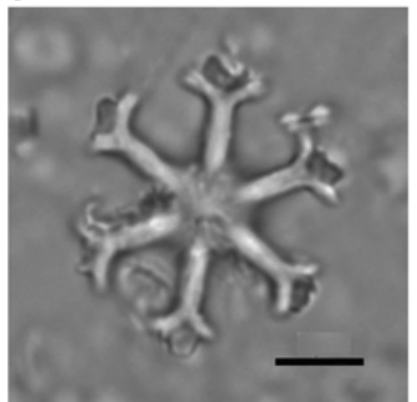

13

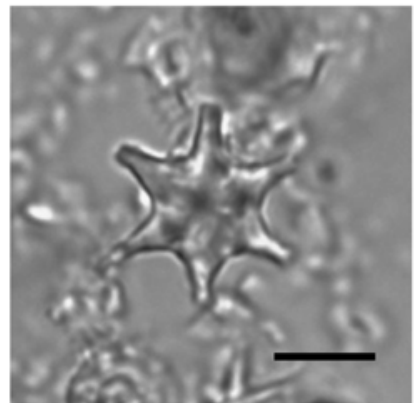

17

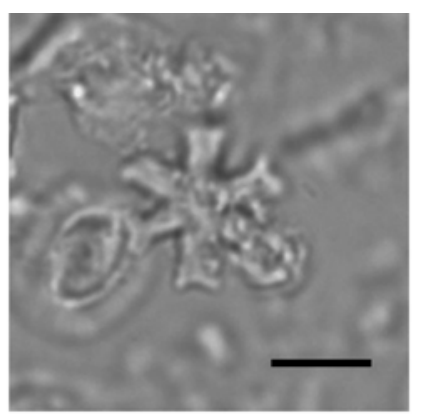

2

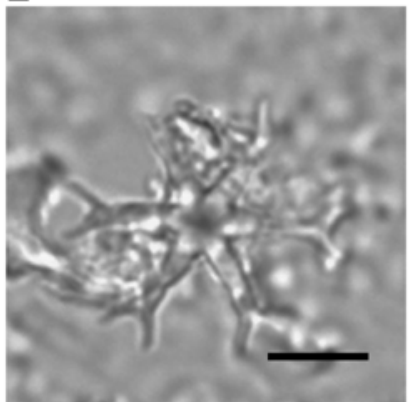

6

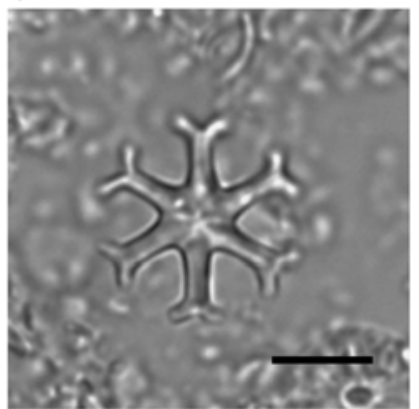

10

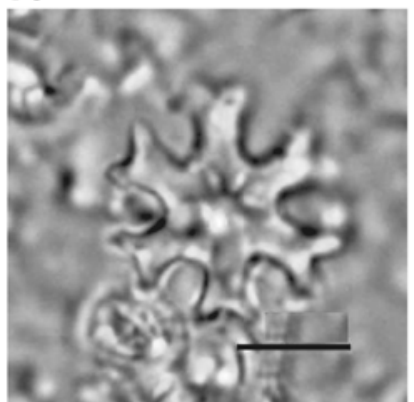

14

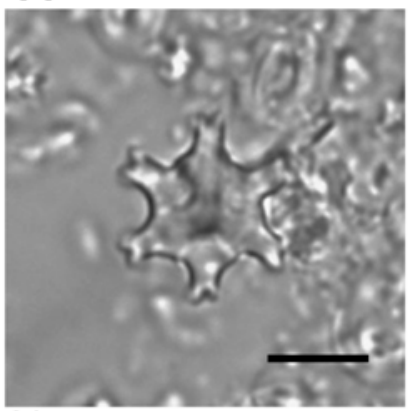

18

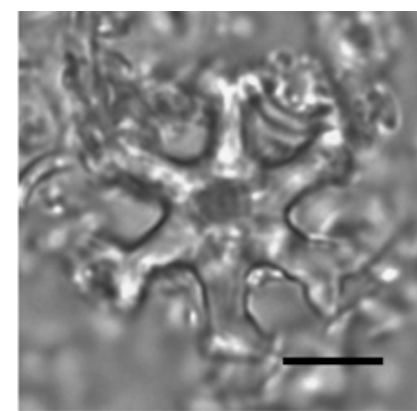

3

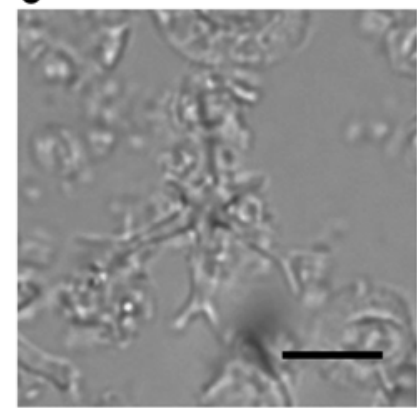

7

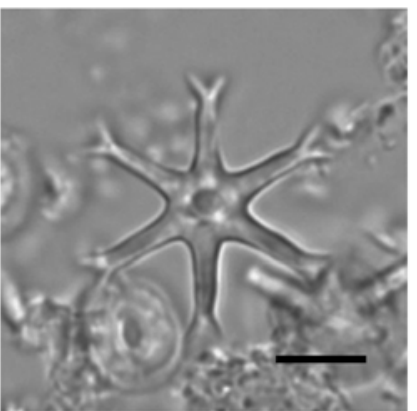

11

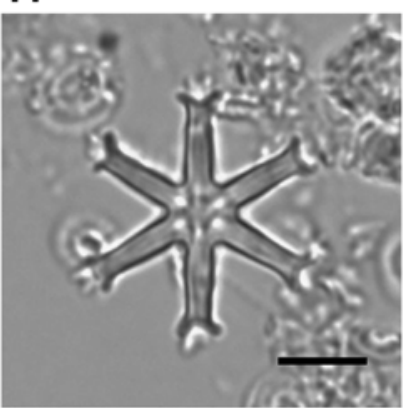

15

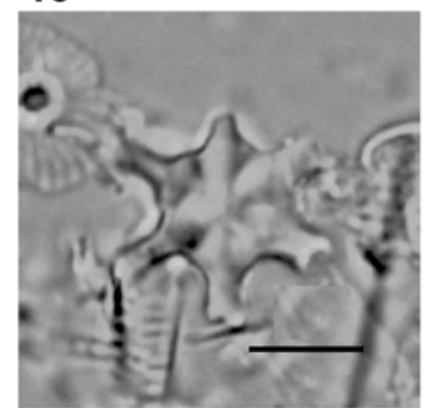

19

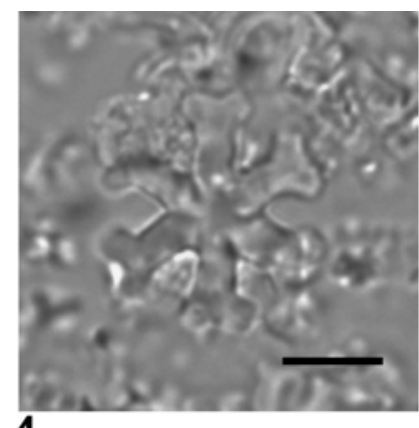

4

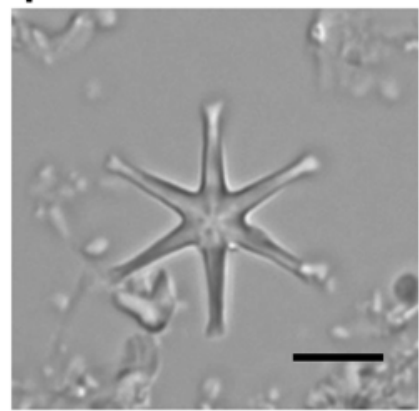

8

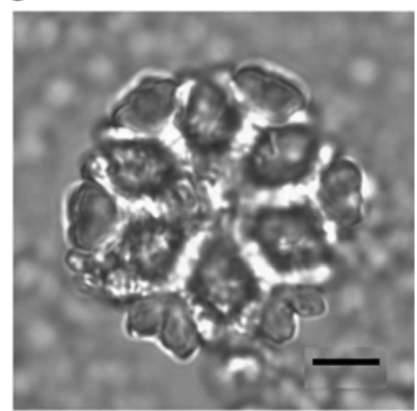

12

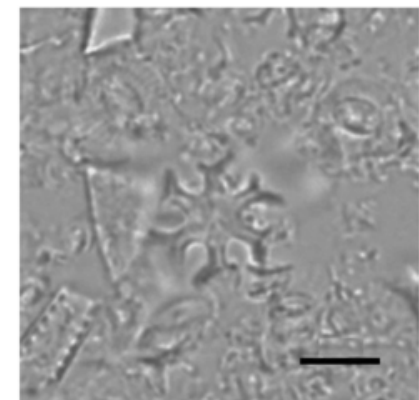

16

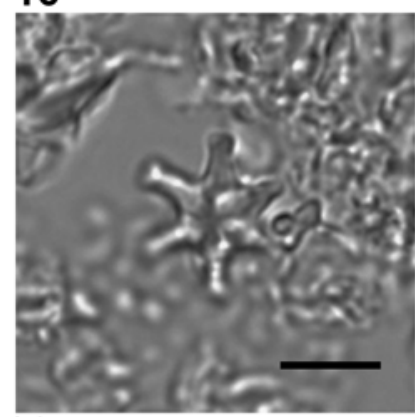

20

Fig. 1. 1, Discoaster deflandrei (sample U1338C-46H-2, 45-46 cm). 2, Intergrading form Discoaster deflandrei-Discoaster variabilis (sample U1338C31H-3, $122-123 \mathrm{~cm}$ ). 3, Discoaster aulakos (sample U1338B-26H-5, 120-121 cm). 4, Discoaster divaricatus (sample U1338C-44H-2, 120 - 121 cm). 5, Discoaster woodringi (sample U1338C-46H-5, 45-46 cm). 6, Discoaster signus (sample U1338C-39H-2, $122-123 \mathrm{~cm}$ ). 7, Discoaster cf. signus (sample U1338C-41H-6, $44-45 \mathrm{~cm}$ ). 8, Discoaster exilis (sample U1338A-25H-2, 80 - $81 \mathrm{~cm}$ ). 9, Discoaster cf. exilis (sample U1338B-42H-4, 45 - 46 cm). 10, Discoaster variabilis (sample U1338B-18H-4, $45-46 \mathrm{~cm}$ ). 11, Intergrading form Discoaster variabilis-Discoaster exilis (sample U1338A-25H-3, $80-81 \mathrm{~cm}$ ). 12, Discoaster icarus (sample U1338B-18H-6, 120-121 cm). 13, Intergrading form Discoaster variabilis-Discoaster icarus (sample U1338B-16H-3, $120-121 \mathrm{~cm}$ ). 14, Discoaster cf. bollii (sample U13384-24H-4, 58-59 cm). 15, Discoaster surculus (sample U1338A-24H, CC). 16, Discoaster loeblichii (sample U1338A-18H-6, 45 - 46 cm). 17- 18, Discoaster kugleri (sample U1338B-28H-6, 45 - 46 cm). 19-20, Discoaster musicus (19 - sample U1338A-25H-4, 120 - $121 \mathrm{~cm} ; 20$ - sample U1338B-33H-5, $45-46 \mathrm{~cm}$ ). Scale bar $5 \mu \mathrm{m}$. 

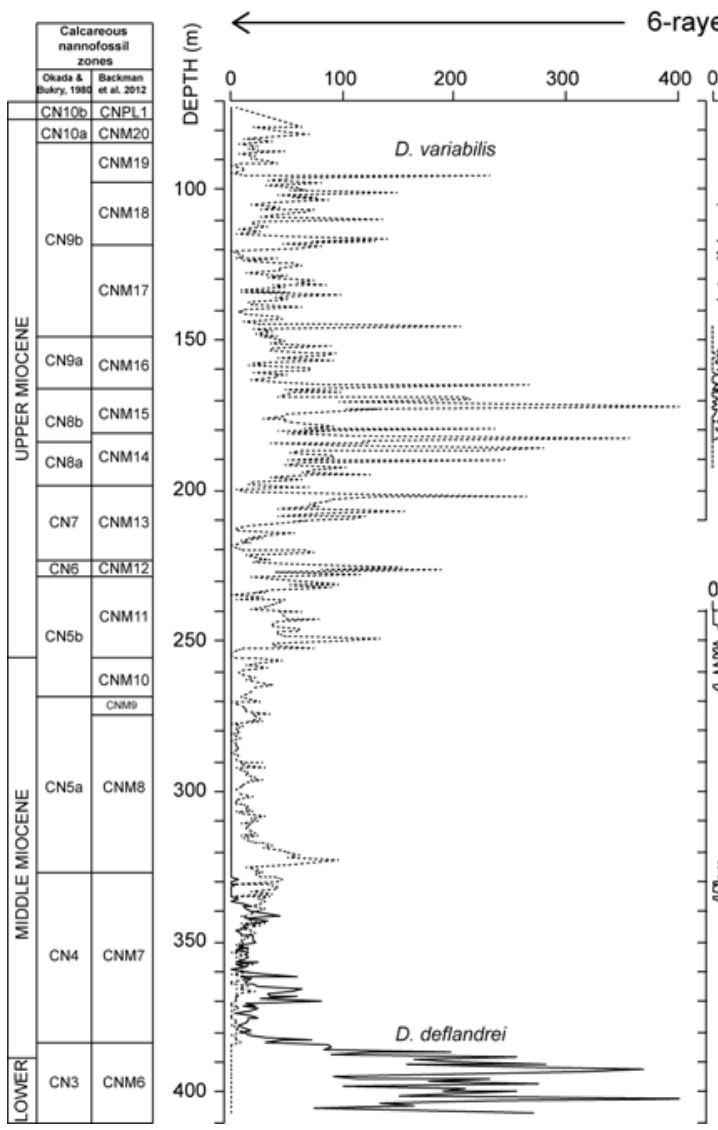

rayed morphotypes with bifurcated ray tips $\left(n \mathrm{~mm}^{-2}\right)$

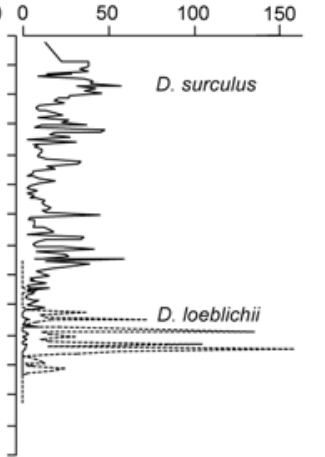

Fig. 2. Abundance data as number of specimens of six-rayed discoasters having bifurcated ray tips in a prefixed area on the smear-slide at Site U1338. Biozonations from Okada \& Bukry (1980) and Backman et al. (2012). Depth refers to compressed metres composited depth (see 'Methods' section). (IG) denotes specimens showing intergrading morphology between two species.

whose morphology is created by secondary calcite overgrowth (Roth \& Thierstein 1972; Aubry 1984; Rio et al. 1990). This view is supported by our observations from Site U1338, where D. woodringi morphotypes occur in the lowermost part of the sequence where the preservation of nannofossil assemblages is deteriorated by calcite overgrowth and/or dissolution.

Discoaster aulakos and D. divaricatus (Fig. 1:3-1:4) were observed in middle Miocene sediments at Site U1338. Aubry (1984) described in detail the differences between these species. In the census data from Site U1338, however, we grouped these similar-looking morphotypes in the broader $D$. deflandrei concept, thus avoiding splitting the group on the basis of preservational biases caused by overgrowth and/or dissolution, and allowing for some degree of intra-specific morphological variation of $D$. deflandrei. This grouping was made despite the fact that some specimens referable to the $D$. aulakos and $D$. divaricatus concepts were observed. Many other specimens, however, could not be properly separated from $D$. deflandrei. Furthermore, D. aulakos and

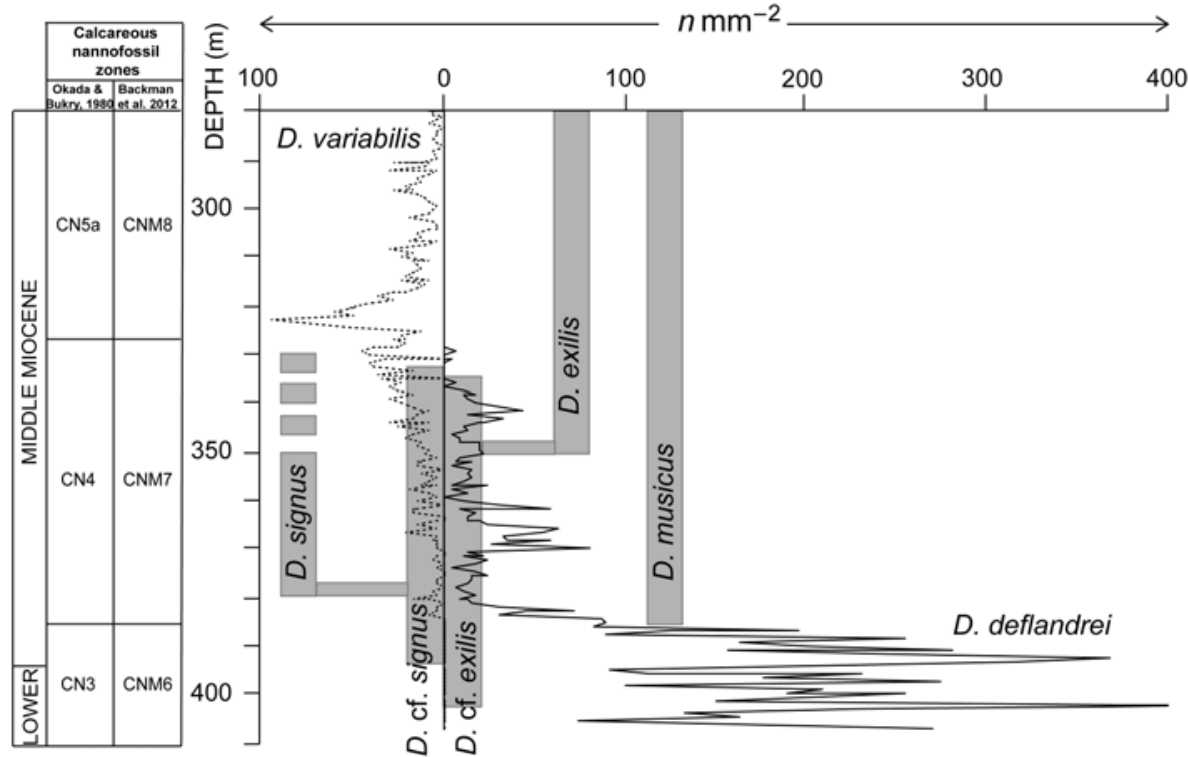

Fig. 3. Sequence of Discoaster evolutionary events across the early/ middle Miocene boundary at Site U1338, together with abundance data of $D$. deflandrei and $D$. variabilis. These changes represent the first major evolutionary transition among Miocene discoasters. Biozonations from Okada \& Bukry (1980) and Backman et al. (2012). Depth refers to compressed metres composited depth (see 'Methods' section). These changes represent the first major evolutionary transition among Miocene discoasters. 


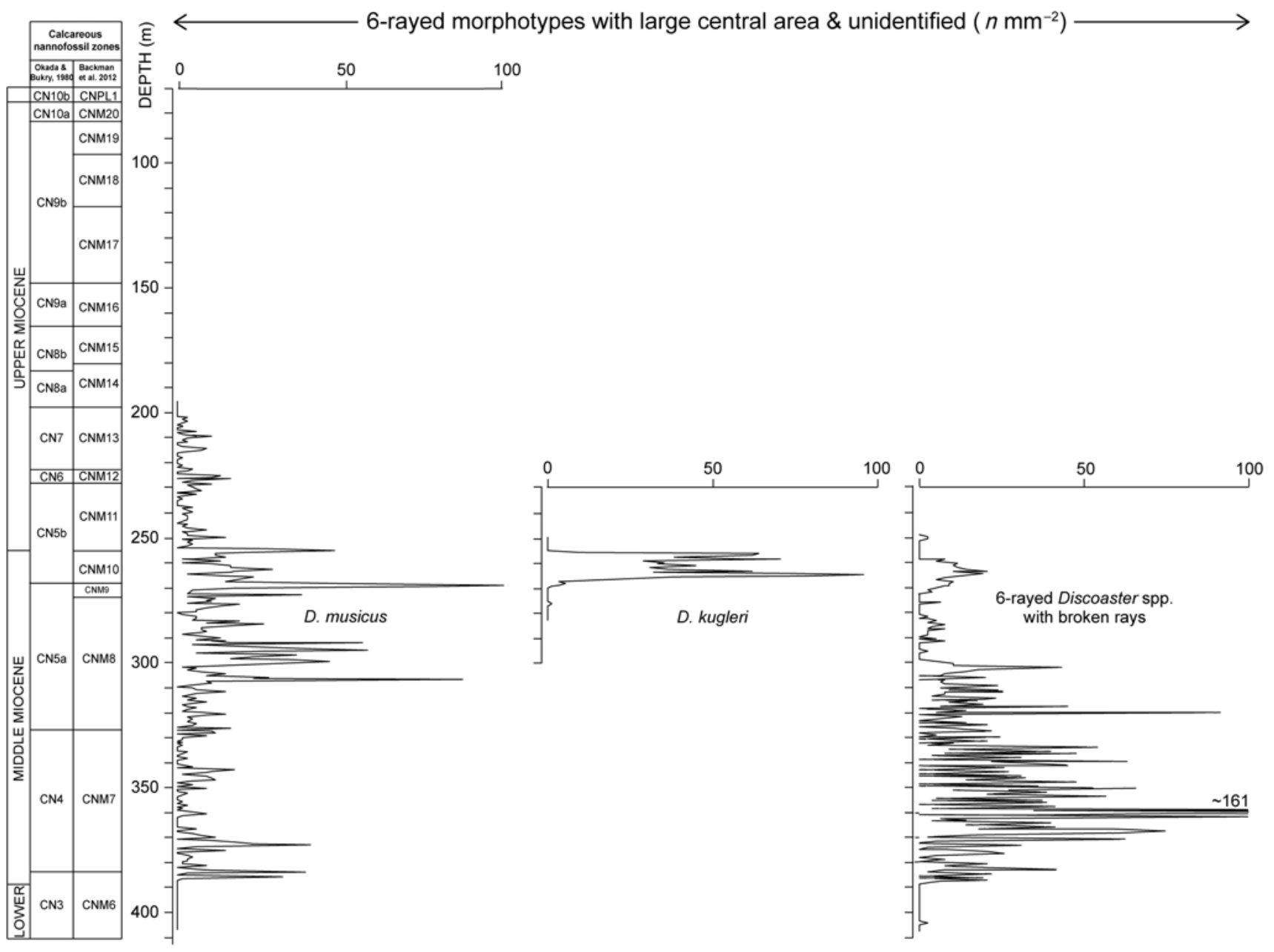

Fig. 4. Abundance data as number of specimens of six-rayed discoasters having large central areas in a prefixed area on the smear-slide at Site U1338. Biozonations from Okada \& Bukry (1980) and Backman et al. (2012). Depth refers to compressed metres composited depth (see 'Methods' section).

D. saundersi have been considered to represent 'an intermediate variety between $D$. deflandrei and $D$. exilis' by Jeremy Young (16 March 2011, nannotax.org), who also considers both $D$. divaricatus and $D$. saundersi to be synonyms of $D$. deflandrei.

Bukry (1973b, p. 692) noticed that

[a] reduction in the dominance of Discoaster deflandrei at the top of the zone [H. ampliaperta Zone] in favor of long-rayed discoasters such as $D$. exilis, D. signus, and D. variabilis is distinctive in low-latitude areas

and referred to this as an 'end of Acme' of $D$. deflandrei without quantifying the concept. Subsequently, Rio et al. (1990) quantified this biohorizon as when the abundance of $D$. deflandrei decreased to values below $30 \%$ among the total Discoaster assemblage, and remarked that this event coincides with the appearance of $D$. signus. These changes occur also at Site U1338, together with the appearances of $D$. variabilis and morphotypes here referred to as $D$. cf. exilis (Figs 2 and 3).

The exact position of the $D$. deflandrei decline, however, is obscured at Site U1338 because of poor preservation among many specimens that belong to the $D$. deflandrei/D. variabilis plexus together with presence of morphotypes showing intergrading morphologies between the two morphotype end-members (Fig. 2). This makes it difficult to apply the 30\% rule if taking into account also poorly preserved and intergrading forms (D. deflandrei-D. variabilis (IG) in Fig. 2) in the lowermost part of the investigated sequence at Site U1338. However, if taking into account only specimens that have been identified with certainty as D. deflandrei, the $30 \%$ limit distinctly falls between 384.92 and $385.60 \mathrm{~m}$ (Fig. 2).

Discoaster icarus (Fig. 1:12) is another robust six-rayed form that shows morphological similarities with 'species' in the $D$. deflandrei group. This morphotype is separated, however, from the D. deflandrei group in terms of its restricted stratigraphic distribution in sediments of Messinian age (Stradner 1973). Discoaster icarus thus appeared about eight million years after the top of common D. deflandrei in the lowermost middle Miocene (Backman et al. 2013). Discoaster icarus is a large, up to $30 \mu \mathrm{m}$, morphotype characterized by its large central area bearing a hexagonal or prismatic knob on the distal side and sutures on both the distal and proximal sides. The sutures delineate the roots of six robust rays ending in wide-angled bifurcations and presence of a membrane-like structure between them (Stradner 1973; Aubry 1984). This morphotype is rare at Site U1338, whereas specimens showing intermediate morphologies with D. variabilis (Fig. 1:13) are more common (Fig. 2).

\section{The Discoaster variabilis group}

Discoaster variabilis was originally described by Martini \& Bramlette (1963), a species characterized by long and slender rays that may bend slightly, and having bifurcating ray tips. The D. variabilis concept refers to discoasters with a large degree of morphological variability due to differences in ray numbers $(3-6)$, ray terminations and central area sizes. The bifurcations can be more or less developed and sometimes show a web between them (Aubry 1984). This is evident in the sporadic occurrences of intermediate 


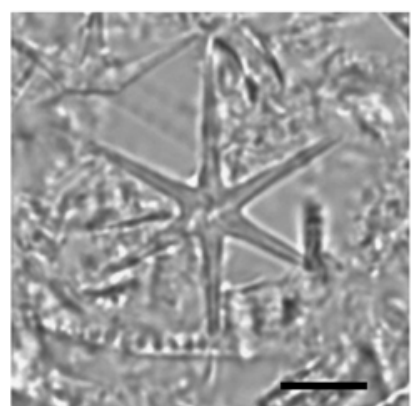

1

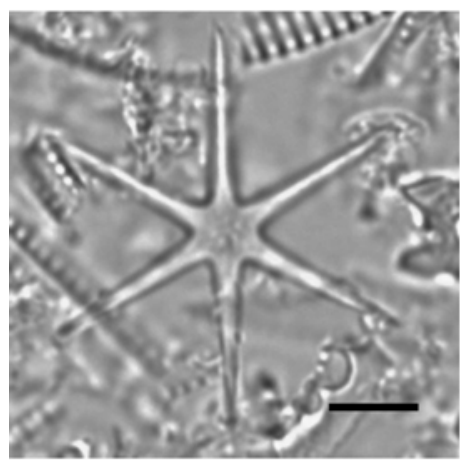

5

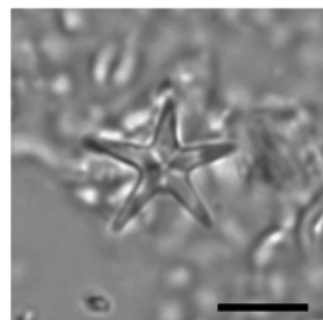

8

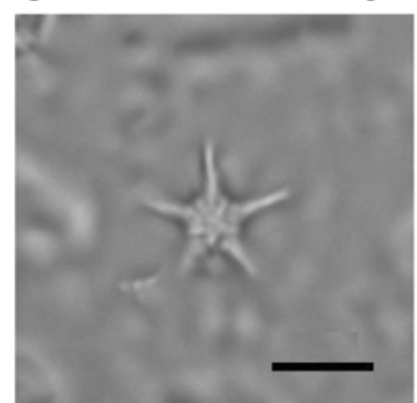

13

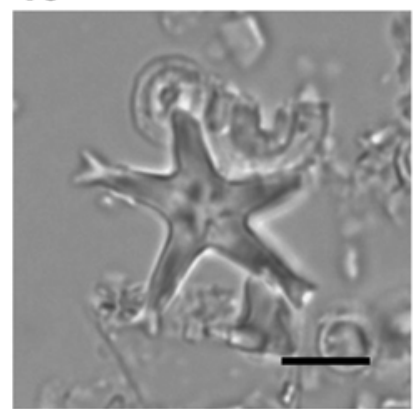

17

9

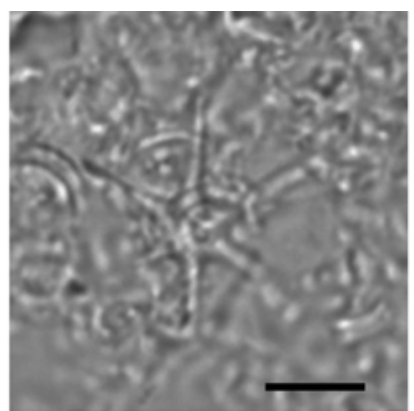

2

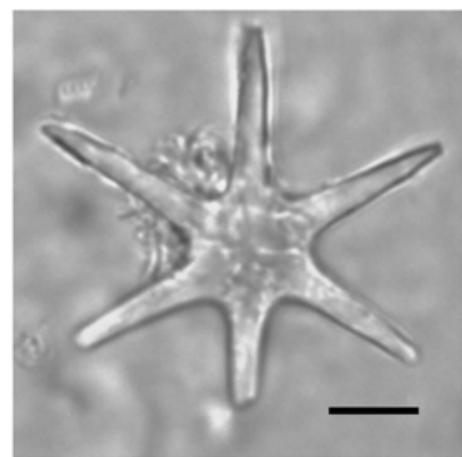

6

\section{3}
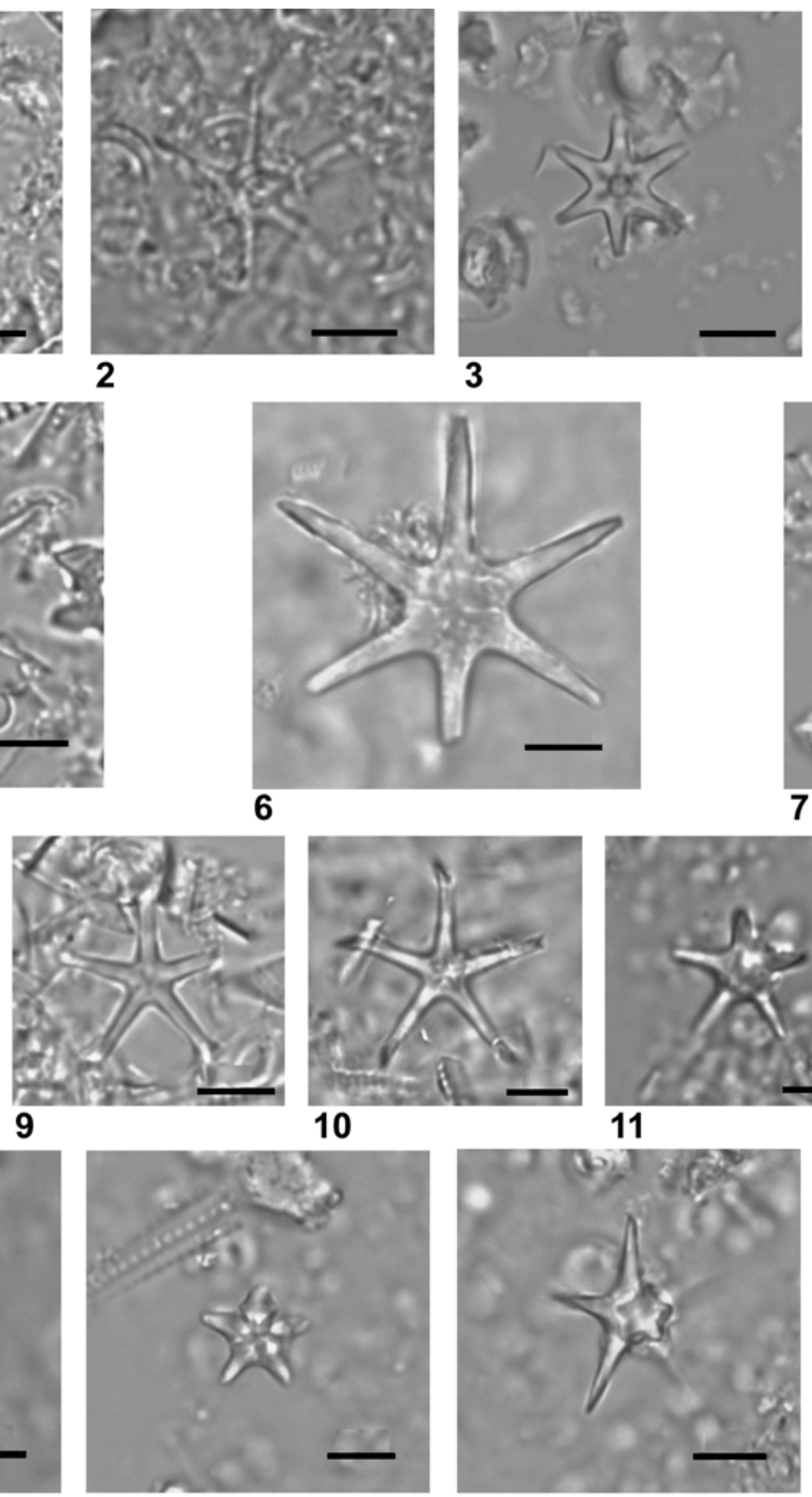

14

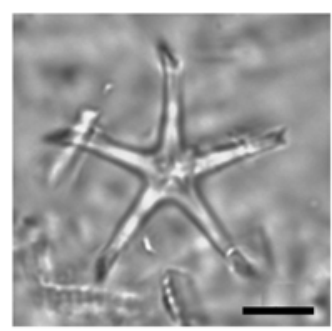

10

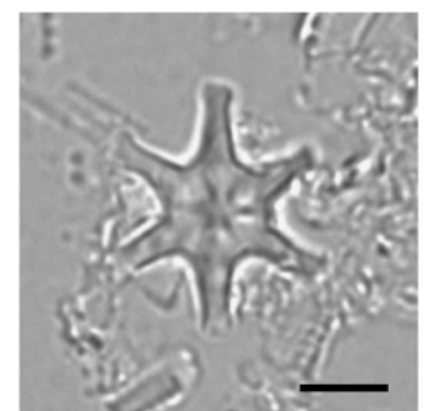

4

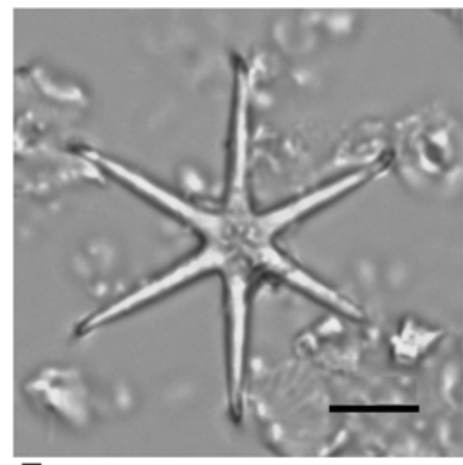

7

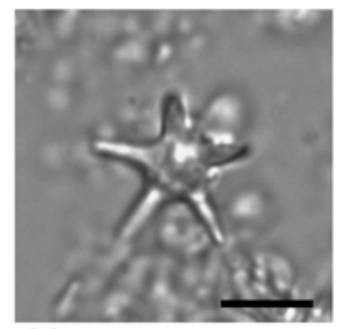

11

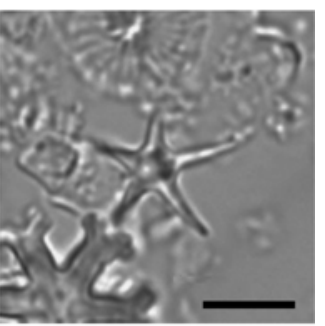

12

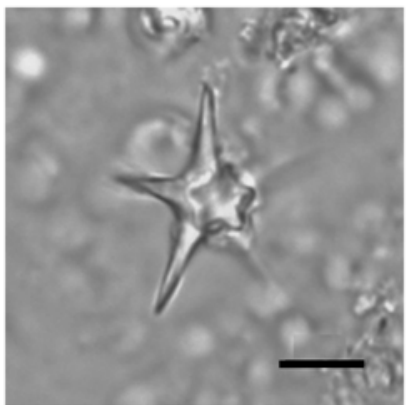

15

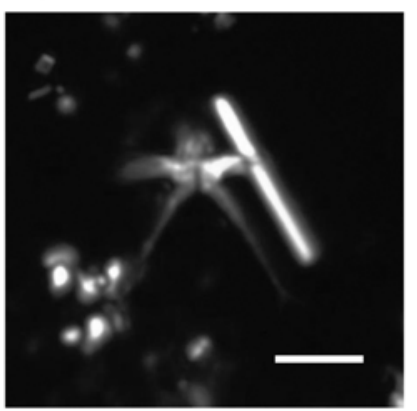

19

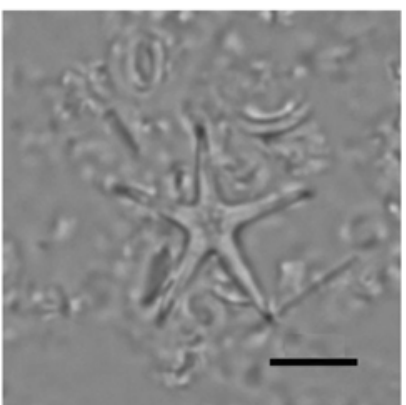

16

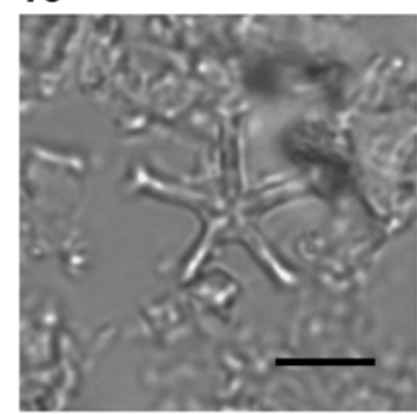

20

Fig. 5. 1, Discoaster brouweri (sample U1338A-13H-3, 120-121 cm). 2, Discoaster cf. brouweri (sample U1338C-31H-3, 122 - 123 cm). 3, Discoaster intercalaris (sample U1338A-22H-5, $80-81 \mathrm{~cm}$ ). 4, Intergrading form Discoaster variabilis-Discoaster intercalaris (sample U1338A-19H-5, 45 - 46 cm). 5, Discoaster brouweri $>20 \mu \mathrm{m}$ (sample U1338A-13H-3, 120-121 cm). 6, Discoaster neorectus (sample U1338A-18H-5, 120 - 121 cm). 7, Discoaster neohamatus (sample U1338B-13H-2, 120 - $121 \mathrm{~cm}$ ). 8, Discoaster bellus (sample U1338B-18H-5, 120 - 121 cm). 9, Intergrading form Discoaster bellusDiscoaster hamatus (sample U1338B-24H-3, 142-143 cm). 10, Discoaster hamatus (sample U188A-24H-2, 68-69 cm). 11 - 12, Intergrading form Discoaster bellus-Discoaster berggrenii (11 - sample U1338B-18H-5, 120 - $121 \mathrm{~cm} ; 12$ - sample U1338B-18H-4, 45 - 46 cm). 13 - 14, Discoaster berggrenii (13 - sample U133A-18H-6, 45 - 46 cm; 14 - sample U1338B-13H-2, 120 - $121 \mathrm{~cm})$. 15, Discoaster quinqueramus (sample U1338B-13H-2, 120 - $121 \mathrm{~cm}$ ). 16, Discoaster asymmetricus (sample U1338A-16H-3, 45 - $46 \mathrm{~cm}$ ). 17, Discoaster moorei (sample U1338A-25H-3, 80 - 81 cm). 18-19, Discoaster pentaradiatus (sample U1338A-9H-5, $70-71 \mathrm{~cm}$ ). 20, Discoaster prepentaradiatus (sample U1338A-21H-2, 66-67 cm). Scale bar 5 um. 


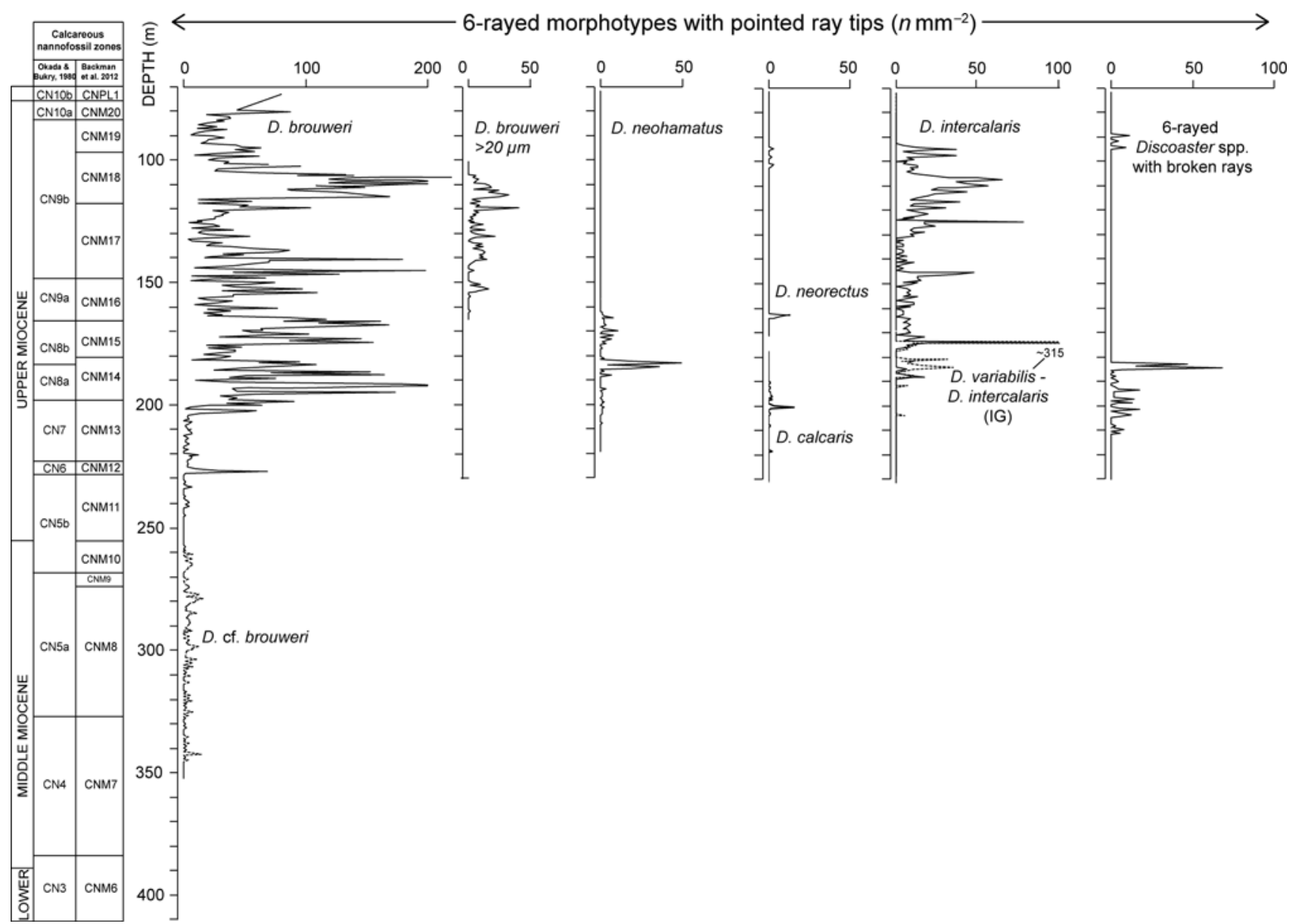

Fig. 6. Abundance data as number of specimens of six-rayed discoasters having pointed ray tips in a prefixed area on the smear-slide at Site U1338. The rapid rise of D. brouweri close to $200 \mathrm{~m}$ is a key part of the second major evolutionary transition among Miocene discoasters (see also Figs 10 and 11 ). Biozonations from Okada \& Bukry (1980) and Backman et al. (2012). Depth refers to compressed metres composited depth (see 'Methods' section). (IG) denotes specimens showing intergrading morphology between two species. Notice $16 \mathrm{~m}$ stratigraphic gap between the disappearance of $D$. cf. brouweri and appearance of D. brouweri. Plot modified from Backman et al. (2013).

specimens between $D$. variabilis and $D$. icarus, recorded in a restricted stratigraphic interval from 227.40 to $138.81 \mathrm{~m}$ (Figs 1:13, 2). Intermediate specimens between $D$. variabilis and $D$. exilis also exist (Figs 1:11,2). These differences have resulted in descriptions of several species that are here informally referred to the D. variabilis group. Examples include D. challengeri, described by Bramlette \& Riedel (1954), and Discoaster variabilis pansus, described by Bukry \& Percival (1971). In their discussion of this sub-species, Bukry \& Percival informally referred to the 'main stock' of $D$. variabilis as $D$. variabilis variabilis.

It seems plausible that the phenomenon of hybridization involves $D$. variabilis and other discoasters like $D$. exilis and $D$. intercalaris. The central area is well developed and in the convex side a stellate knob is present while, in the concave side, small ridges run out from the central knob along the median line of each ray (Aubry 1984). Young (1998) suggests that $D$. variabilis evolved from D. exilis during the early late Miocene while Prins (1971) and Theodoridis (1984) argue that $D$. variabilis evolved from $D$. deflandrei.

Discoaster exilis was described by Martini \& Bramlette (1963) and has six long rays with bifurcated tips. At Site U1338, this species was occasionally difficult to recognize due to calcite overgrowth. Specimens referred to as $D$. cf. exilis (Fig. 1:9) are recorded from below and into the range of typical $D$. exilis (Figs 1:8,2) and overlap with the uppermost range of members belonging to the $D$. deflandrei group. Specimens of $D$. cf. exilis differ from $D$. exilis in lacking the typical ridges along the rays. Intermediate forms between $D$. variabilis and $D$. exilis are common, having an overall structure similar to that of $D$. variabilis and the bifurcated terminations of $D$. exilis.

Discoaster signus is characterized by thin bifurcated terminations and a prominent knob in the central area. Moshkovitz \& Ehrlich (1980) and Filewicz (1985) described two species, Discoaster petaliformis and Discoaster tuberi, respectively, that Backman et al. (2012) consider to be junior synonyms of D. signus. Specimens similar to $D$. signus were observed below and throughout the range of typical $D$. signus (Figs 1:6,2). These morphotypes, referred to as $D$. cf. signus, have small and thin bifurcations and an outline similar to that of D. signus but lack the typical star-shaped central knob (Fig. 1:7) and are here considered to represent intermediate forms between $D$. signus and $D$. exilis.

According to the abundance data from Site U1338, there appears to be an evolutionary step-like succession from $D$. deflandrei to $D$. variabilis to $D$. signus to $D$. exilis (Fig. 3 ). The major decrease in $D$. deflandrei near $385 \mathrm{~m}$ occurs together with the first occurrence of typical $D$. variabilis, closely followed by the first typical $D$. signus. The final step is the occurrence of the first typical D. exilis together with the final occurrence of typical $D$. deflandrei. This suggests that $D$. deflandrei may be the ancestor of $D$. variabilis as well as $D$. signus and $D$. exilis. The roles of $D$. cf. signus and $D$. cf. exilis in this evolutionary succession are unclear, partly because preservational problems are involved in our designation of these morphotypes and partly because genuine evolutionary transitions cannot be excluded; these morphotypes may represent 'precursors' of the typical D. signus and D. exilis. 


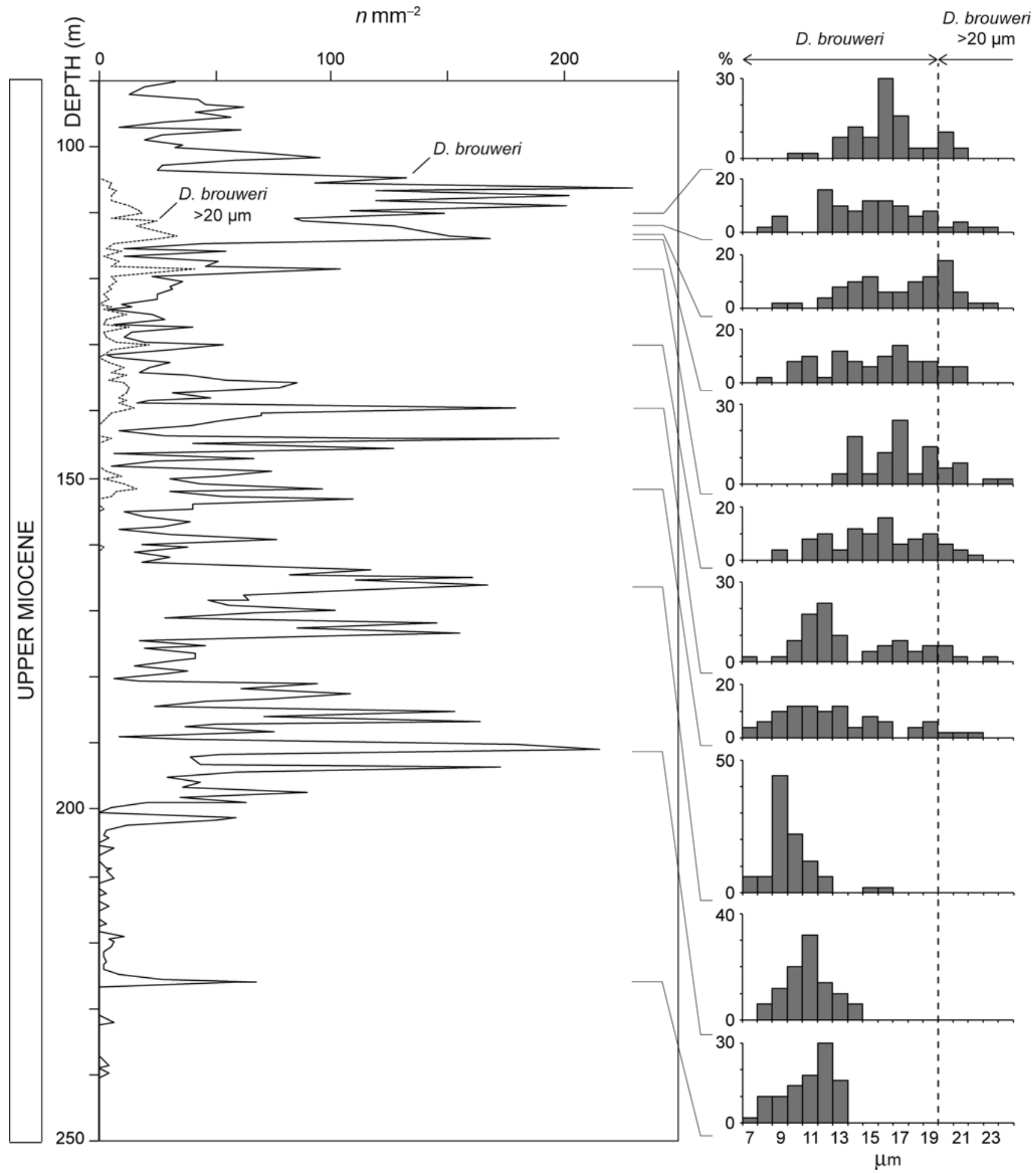

Fig. 7. Abundances and biometry of D. brouweri in the late Miocene, revealing a nearly $50 \%$ size increase, on average. Specimens $>20 \mu \mathrm{m}$ are plotted separately in the abundance plot, following the Discoaster sp. 2 concept of Rio et al. (1990) and Raffi et al. (1995). Histograms represent relative abundances (\%) using $1 \mu \mathrm{m}$ size increments. Data were acquired using the image analysis software Image-Pro Plus 6.2.

Typical Discoaster bollii, characterized by short tapering, bifurcated rays and a distinct central knob, have not been observed at Site U1338. Rare specimens approaching the morphology of $D$. bollii were, however, observed (Fig. 1:14), referred to as $D$. cf. bollii.

Discoaster surculus and D. loeblichii represent two species with six slender and bifurcated rays observed at Site U1338 (Fig. 1:15-1:16). Bukry (1973b) suggested that $D$. surculus may have evolved from $D$. pseudovariabilis, a species not observed at Site U1338. Discoaster loeblichii is well preserved at Site U1338 with specimens having the typical asymmetrical bifurcation of the ray tips.

In the middle Miocene sediments at Site U1338, the abundance of other six-rayed discoasters having bifurcated ray tips which could not be confidently referred to either the $D$. deflandrei group or the $D$. variabilis group because of overgrowth problems or intergrading morphologies have been counted separately (Fig. 2). These specimens are here referred to as $D$. deflandrei-D. variabilis intergrading (IG) morphotypes (Fig. 1:2). In this middle Miocene interval, poorly preserved six-rayed discoasters are present, having 


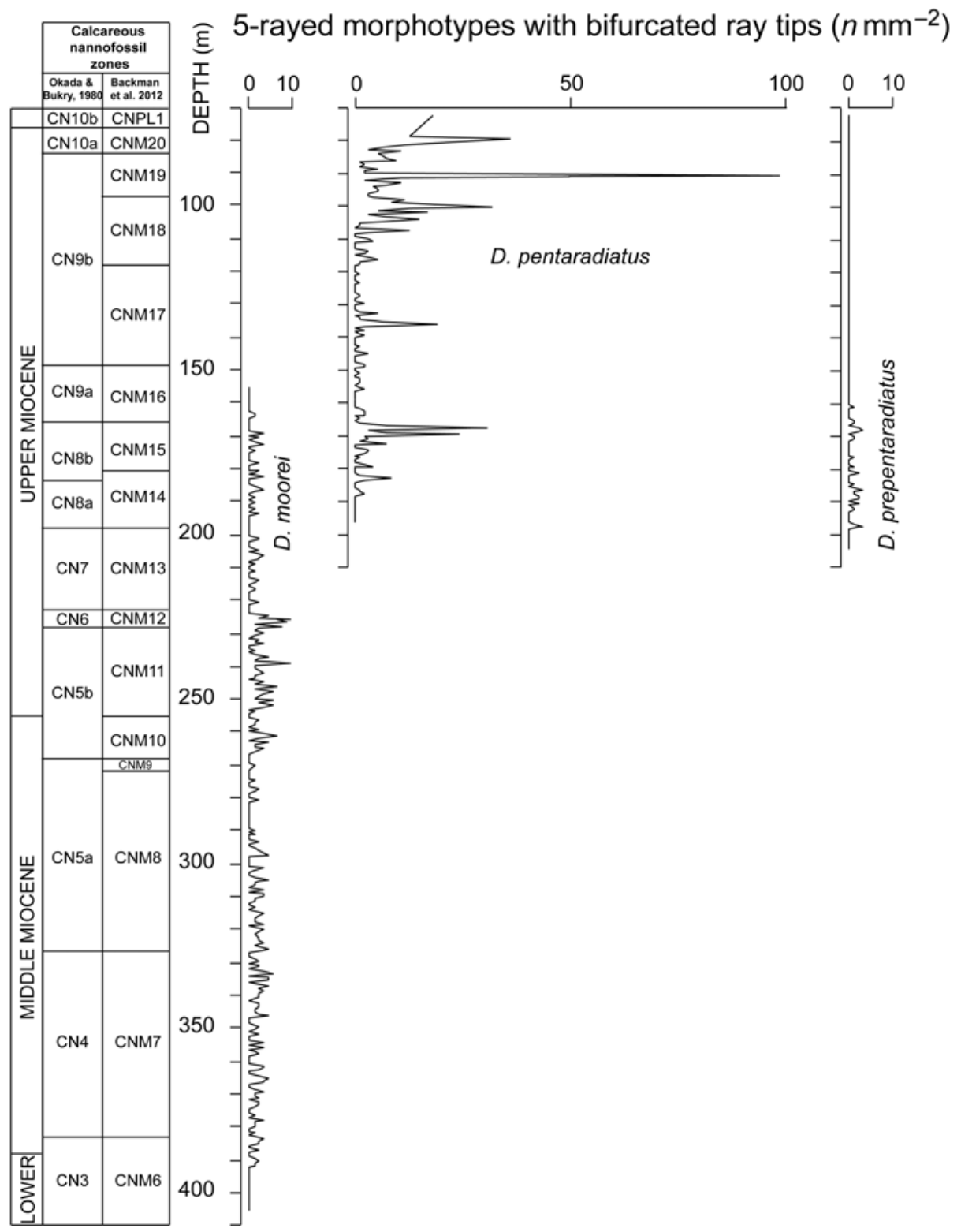

Fig. 8. Abundance data as number of specimens of five-rayed discoasters having bifurcated ray tips in a prefixed area on the smear-slide at Site U1338. Biozonations from Okada \& Bukry (1980) and Backman et al. (2012). Depth refers to compressed metres composited depth (see 'Methods' section).

the outer portion of one or several rays broken off, referred to as '6-rayed Discoaster spp. with broken rays'. These may represent D. deflandrei, D. deflandrei-D. variabilis (IG), D. variabilis, $D$. signus, $D$. cf. signus, $D$. exilis or $D$. cf. exilis.

\section{Six-rayed morphotypes with a large central area}

A group of six-rayed discoasters characterized by a large central area includes the middle Miocene species D. musicus, D. sanmiguelensis and D. kugleri (Fig. 1:17-1:20). Discoaster musicus and D. sanmiguelensis were described by Stradner (1959) and Bukry (1981), respectively, using similar diagnostic characters. A comparison of Stradner's and Bukry's descriptions and illustrations suggests that $D$. sanmiguelensis is a junior synomym of $D$. musicus, as suggested previously by Rio et al. (1990). These morphotypes are here merged under the D. musicus concept (Fig. 4) as it was not possible to consistently separate the two, particularly when calcite overgrowth blurred morphological features. The first appearance of D. musicus at Site U1338 occurs concomitantly with the sharp decrease in abundance of $D$. deflandrei, near $385 \mathrm{~m}$ (Figs $2-4$ ).

The decline in abundance of $D$. deflandrei at c. $385 \mathrm{~m}$ in Site U1338 is characterized by an interval of low abundances prior to its extinction, which may be placed at between 336 and $327 \mathrm{~m}$, marking the end of a successful species that had thrived and dominated the Discoaster assemblages over much of its range, encompassing c. $30 \mathrm{Ma}$. Several new species of bifurcated six-rayed discoasters evolved in the $c .50 \mathrm{~m}$ long stratigraphic interval above the sharp abundance decline of $D$. deflandrei, including $D$. musicus, $D$. variabilis, $D$. signus, $D$. exilis and the pre-cursor morphotypes $D$. cf. signus and D. cf. exilis (Figs 2-4). These changes represent the first of two major evolutionary transitions among Miocene discoasters. The precise phylogenetic relationships among these taxa, that share some morphological characters, and their relationship to $D$. deflandrei, cannot be resolved with the available data from Site U1338, partly due to preservational problems. The most logical ancestor for this development among the six-rayed bifurcated discoasters close to the early/middle Miocene boundary is here considered to be $D$. deflandrei. It is noteworthy that the evolution among the 6-rayed bifurcated discoasters began during the later part of the middle Miocene climate optimum (end of dominance of $D$. deflandrei, appearance of $D$. variabilis) and ended (extinction of $D$. deflandrei, appearance of $D$. exilis sensu stricto) when extensive ice growth began on Antarctica (Holbourn et al. 2014). They demonstrate, using carbon and oxygen isotope data from Site U1338, that this critical interval was characterized by 'high-amplitude climate variations, marked by intense perturbations of the carbon cycle' (Holbourn et al. 2014, pp. 21-22) The combination of marked palaeoclimate variability with major 


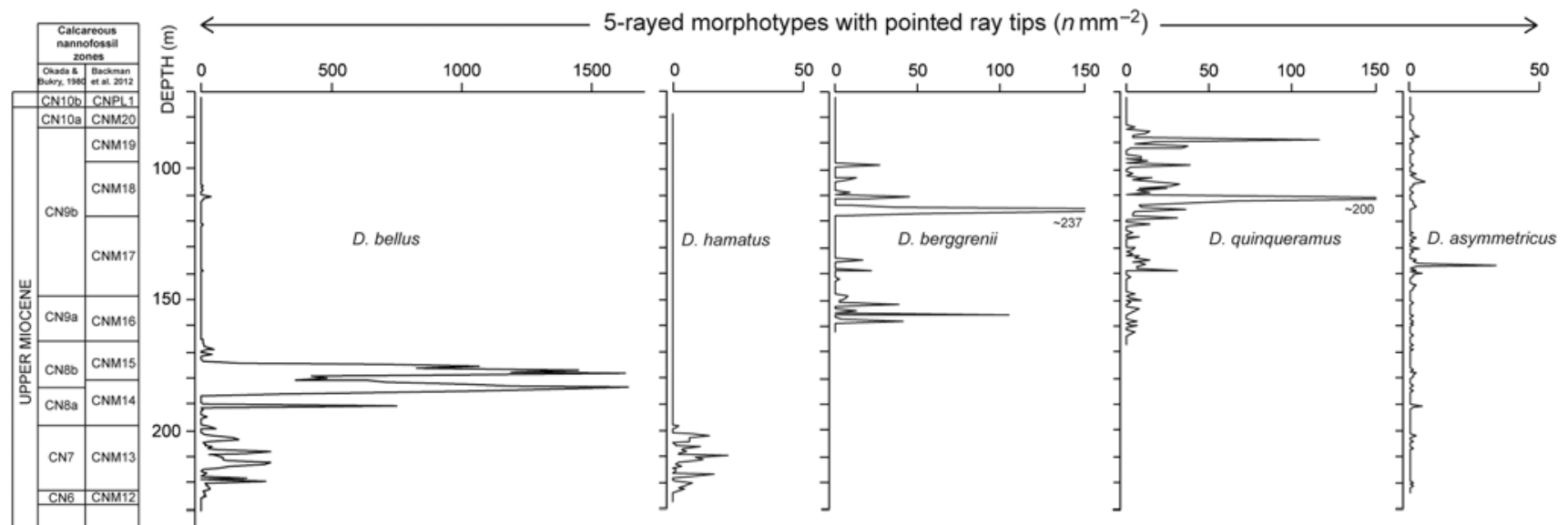

Fig. 9. Abundance data as number of specimens of five-rayed discoasters having pointed ray tips in a prefixed area on the smear-slide at Site U1338. Biozonations from Okada \& Bukry (1980) and Backman et al. (2012). Depth refers to compressed metres composited depth (see 'Methods' section).

biogeochemical changes in the photic zone environments may very well have initiated the major diversification among the middle Miocene Discoaster assemblages.

The species $D$. kugleri exhibits differences in terms of lengths and widths of the rays, the bifurcations of ray tips, and in the size of the central area that may or may not show a central knob or sutures. This species shows high abundances across its short total stratigraphic range at Site U1338 (Fig. 4), defining Zone CNM10.

\section{Six-rayed morphotypes with pointed ray tips}

A group of six-rayed discoasters with pointed ray tips includes D. brouweri, D. cf. brouweri, large morphotype $(>20 \mu \mathrm{m})$ of D. brouweri, D. calcaris, Discoaster intercalaris, D. intercalarisD. variabilis (IG), D. neohamatus and D. neorectus (Fig. 5:1 - 5:7).

Discoaster brouweri has a simple structure, with six, slightly bent, pointed slender rays. The central area is generally small and lacks ornamentation. In larger specimens, the central area may be more developed as well as the arms, resulting in a more massive morphovariant, similar to Discoaster neorectus, which differs from D. brouweri by not having umbrella-like bent rays (Bukry 1971a). This similarity between larger $D$. brouweri and $D$. neorectus may indicate an evolutionary link between the two species. Specimens of D. brouweri having slender and long rays may resemble Discoaster neohamatus. Rio et al. (1990, p. 211) suggested that this diagnostic 'feature is less evident in the specimens found in the terminal range of the species, when intergrade forms to D. brouweri are present'.

Discoaster brouweri is common in upper Miocene sediments at Site U1338 (Figs 5:1, 6). Specimens tentatively referred to as ' $D$. cf. brouweri' are smaller than typical $D$. brouweri and lack the typical umbrella-like bending of the rays (Fig. 5:2). These smaller forms were observed in low and discontinuous numbers in the middle Miocene (Fig. 6) as low as Zone CNM7, in agreement with the observation by Rio et al. (1990) from the tropical Indian Ocean. At
Site U1338, there is a gap in the range between this morphovariant and typical $D$. brouweri.

A large ( $>20 \mu \mathrm{m})$ variety of $D$. brouweri (Fig. 5:5) occurs in the Messinian part of the Miocene at Site U1338. This variety begins at c. $155 \mathrm{~m}$ (Zone CNM16) and continues to $c .105 \mathrm{~m}$ (Zone CNM18), within the range of typical D. brouweri (Fig. 6). Like D. brouweri, this morphovariant is also characterized by a small central area and has been referred to as Discoaster sp. 2 by Rio et al. (1990), who observed a size range from 20 to $30 \mu \mathrm{m}$, from ODP Sites 709-711 in the tropical Indian Ocean. This size range of Discoaster sp. 2 has been reported also from ODP Sites 845 and 848 in the eastern equatorial Pacific (Raffi et al. 1995). Here, we follow Rio et al. (1990) and have plotted forms $>20 \mu \mathrm{m}$ separately (Figs 6 and 7).

Biometric data from image analysis of $D$. brouweri and the large $(>20 \mu \mathrm{m})$ morphovariant are presented in Figure 7, showing that there is no size gap or bimodal size distribution in the transition from the smaller $D$. brouweri specimens to the larger $(>20 \mu \mathrm{m})$ morphotype. We notice that between 225 and $166 \mathrm{~m}$, nearly all D. brouweri specimens are $<14 \mu \mathrm{m}$, whereas in the five samples above $130 \mathrm{~m}$ nearly all specimens are $>12 \mu \mathrm{m}$ (Fig. 7), marking a distinct increase in size among the $D$. brouweri population during late Miocene times from an average of nearly $11 \mu \mathrm{m}$ in the late early Miocene to an average of slightly over $16 \mu \mathrm{m}$ in the late late Miocene. This corresponds to a $49 \%$ size increase through the late Miocene.

Obviously, much more biometric data from multiple sites and environmental settings are needed to acquire a more thorough understanding of the relationship between $D$. brouweri and the large morphotype. The appearance of the latter consistently occurs in Zone CNM16 (CN9a) in the low latitude Indian and Pacific oceans (Rio et al. 1990; Raffi et al. 1995; this study), pointing potentially to a useful lower latitude biostratigraphic marker subdividing the interval between base Discoaster berggrenii and base Amaurolithus primus. 

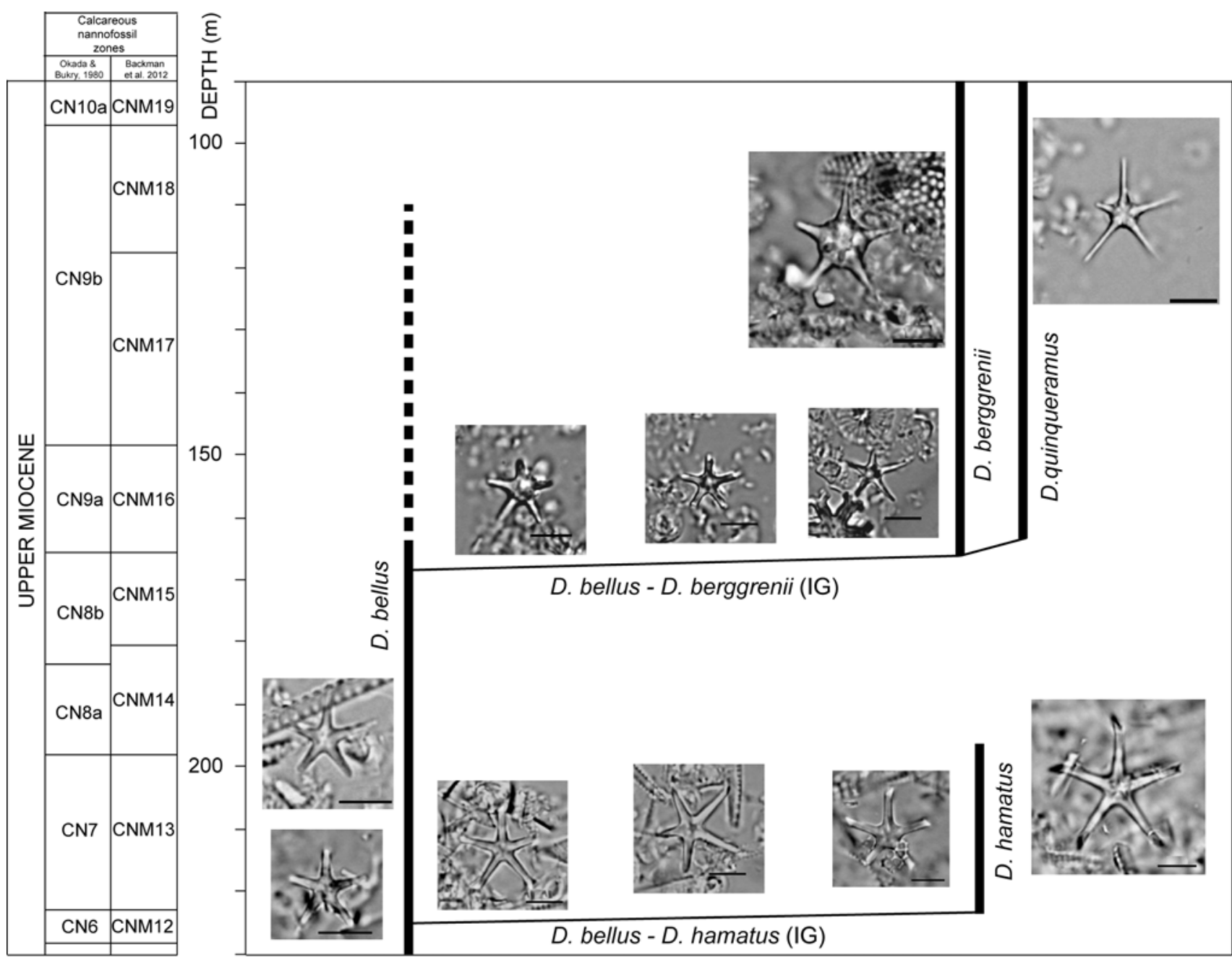

Fig. 10. Successive evolutionary transitions from, first, D. bellus to $D$. hamatus and, second, from $D$. bellus to D. berggrenii/D. quinqueramus. These changes are a key part of the second major evolutionary transition among Miocene discoasters (see also Figs 6 and 11). Biozonations from Okada \& Bukry (1980) and Backman et al. (2012). Depth refers to compressed metres composited depth (see 'Methods' section).

The six slender rays of D. neohamatus are long and delicate and extend from a small and featureless central area (Fig. 5:7). At Site U1338, specimens often show broken or partially dissolved rays, which made accurate identifications at the species level difficult. The category '6-rayed Discoaster spp. with broken rays' in an interval preceding the presence of typical D. neohamatus (Fig. 6) is most probably poorly preserved specimens of $D$. neohamatus with broken ray terminations.

The large $(>20 \mu \mathrm{m}) D$. neorectus is characterized by long straight rays symmetrically arranged with simple tapering tips (Fig. 5:6). Discoaster neorectus occurs discontinuously in low numbers in only six samples at Site U1338 (Fig. 6), similar to what has been observed from the tropical Indian Ocean and the eastern equatorial Pacific Ocean (Rio et al. 1990; Raffi \& Flores 1995). This species consistently overlaps in range with similar-looking large morphotypes of $D$. brouweri, which may suggest an evolutionary relationship between the two. Discoaster calcaris also occurs discontinuously in low numbers in 12 samples (Fig. 6).

Discoaster intercalaris shows much morphological variability, ranging in size from 10 to $16 \mu \mathrm{m}$ and with variable shapes and sizes of the central area and rays, more or less tapering (Fig. 5:3). Intermediate forms with $D$. variabilis, with ray terminations showing a hint of bifurcation, were observed in the lowermost part of its range at Site U1338 (Fig. 5:4). The abundance distributions of these morphotypes are presented in Figure 6.

\section{Five-rayed morphotypes with bifurcating ray tips}

A group of five-rayed discoasters with bifurcating ray tips includes D. moorei, D. pentaradiatus and D. prepentaradiatus (Fig. 5:175:20). The asymmetrical D. moorei, described by Bukry (1971b), has been counted as a separate species (Figs 5:17, 8).

Both birefringent and non-birefringent morphotypes are here included in $D$. pentaradiatus, thereby avoiding the use of the $(E u-)$ discoaster misconceptus concept, introduced by Theodoridis (1984) to distinguish slightly birefringent morphotypes. The slight birefringence is useful for recognition of $D$. pentaradiatus because the ray terminations, with thin and fragile bifurcations, are often broken (Fig. 5:18-5:19). Discoaster prepentaradiatus differs from $D$. pentaradiatus by having a more robust ray structure and lack of the concave-convex ray shape typical of D. pentaradiatus (Fig. 5:20). Both D. prepentaradiatus and D. pentaradiatus show rare and discontinuous occurrences at Site U1338, although the latter may show single sample peaks of higher abundances (Fig. 8).

\section{Five-rayed morphotypes with pointed ray tips}

If the first major evolutionary transition among middle-upper Miocene discoasters was the demise of the $D$. deflandrei group and the emergence of the $D$. variabilis group, the second major transition is the emergence of five-rayed morphotypes with pointed ray tips. 


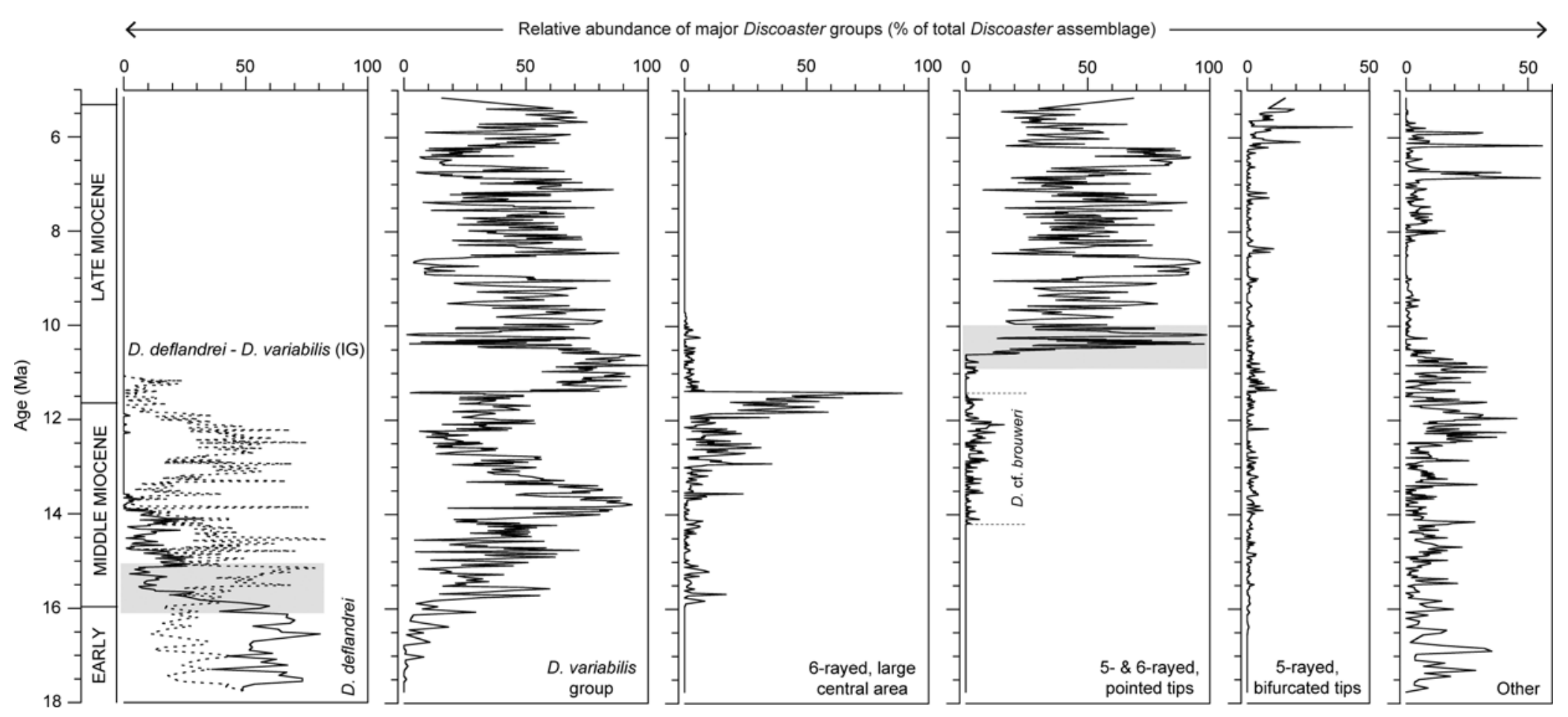

3
0
0
0
0
0
0
0

Fig. 11. Relative abundances (\%) of major groups of Miocene discoasters from Site U1338 plotted against age. Category 'Other' is composed of unidentified six-rayed discoasters, $D$. cf. tristillifer, D. triradiatus and Discoaster A, B, C (Backman et al. 2013). Transparent grey rectangle over $D$. deflandrei and $D$. deflandrei-D. variabilis (IG) panel represents the first major evolutionary transition among Miocene discoasters and the grey rectangle over the panel showing five- and six-rayed discoasters with pointed ray tips represents the second major evolutionary transition among Miocene discoasters. 


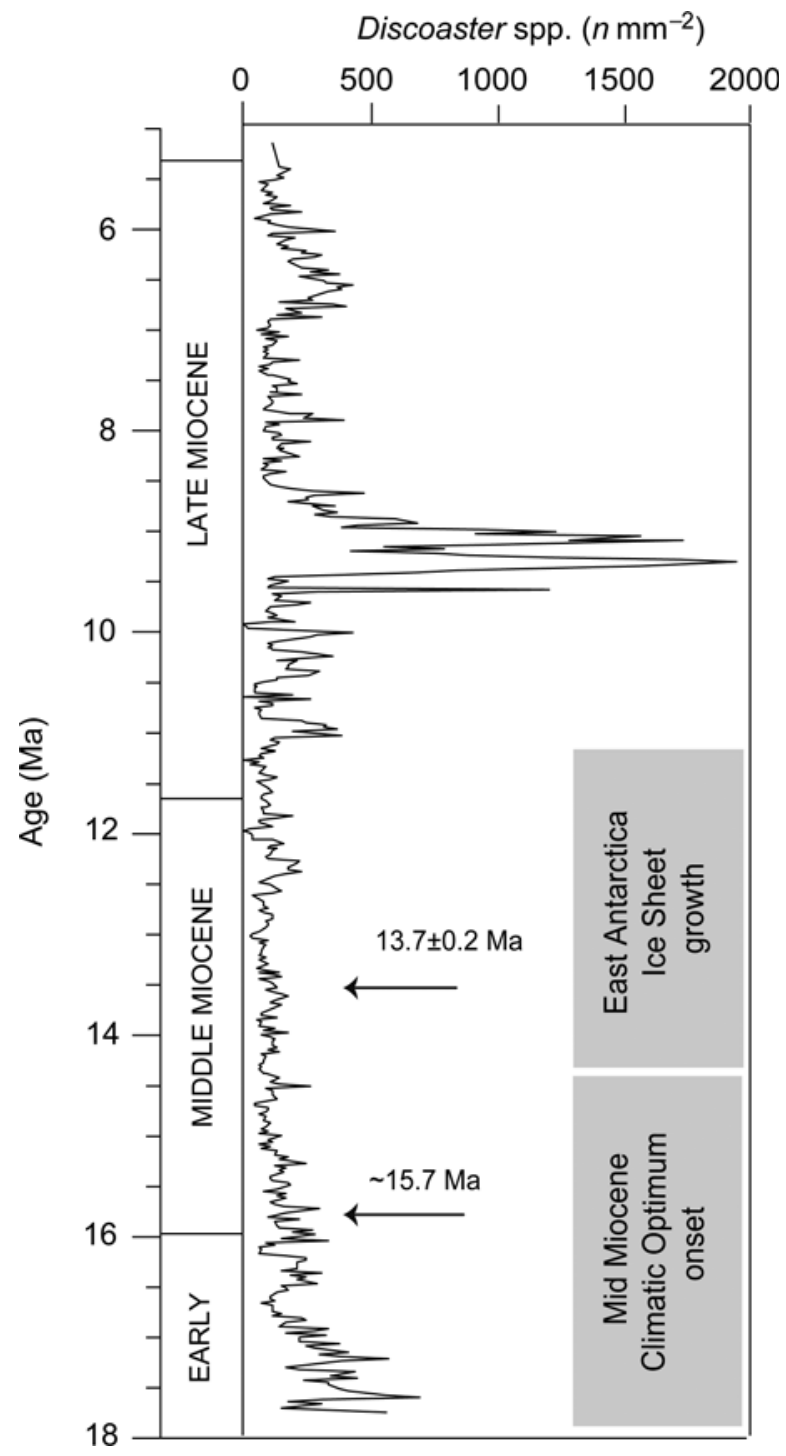

Fig. 12. Total abundance of Discoaster spp. $\left(n \mathrm{~mm}^{-2}\right)$ plotted v. age. The Mid Miocene Climatic Optimum onset and the East Antarctica Ice Sheet growth are indicated by arrows.

Five-rayed discoasters with pointed ray tips include D. asymmetricus, D. bellus, D. berggrenii, D. quinqueramus, $D$. hamatus and intergrading forms (Figs 5:8-5:16,9). The simple structure of $D$. bellus represents a new evolutionary development among the late Miocene Discoaster populations, that occurred after the long period of dominance of six-rayed forms during the Oligocene and through the early and middle Miocene. Discoaster bellus (Fig. 5:8) is the ancestor of three other symmetrical five-rayed discoasters that subsequently evolved during the late Miocene, namely $D$. hamatus, $D$. berggrenii and $D$. quinqueramus. This evolutionary progression is manifested by the presence of specimens showing intermediate morphologies between $D$. bellus and D. hamatus (Figs 5:9, 10), and D. bellus and D. berggrenii (Figs $5: 11-5: 12,10)$, respectively, previously noticed also by Rio et al. (1990) and Raffi et al. (1998).

Discoaster quinqueramus (Fig. 5:15) evolved from $D$. berggrenii through a gradual increase in ray length and decrease in central area size (Raffi et al. 1998). The presence of specimens with intergrading morphologies between $D$. berggrenii and $D$. quinqueramus may make the distinction of the two species difficult.

The $D$. hamatus concept used here refers only to five-rayed morphotypes (Figs 5:10, 9), following Perch-Nielsen (1985). Forms showing intergrading morphologies between D. bellus and $D$. hamatus have been recorded just below and along the range of D. hamatus (Fig. 10).

\section{Major traits of Miocene discoasters at IODP Site U1338}

Above, the abundance patterns of discoasters are plotted v. depth. When summarizing the key trends among these patterns, we consider it useful to plot the data v. age using a low-resolution age model of Site U1338 (Backman et al. 2016). Discoasters reveal distinct traits over the late early Miocene through late Miocene interval at Site U1338 (Figs 11 and 12). These features reflect a dynamic evolution within the Discoaster genus, characterized by sudden events of speciation/extinction which are of key importance for the biostratigraphic characterization of Miocene. The most prominent among these are:

(1) the dominance of $D$. deflandrei prior to $15.8 \mathrm{Ma}$;

(2) the evolution of and rapid oscillations in relative abundance of the D. variabilis group from $<20 \%$ to over $70 \%$ of the total Discoaster assemblage in the late Miocene;

(3) the rapid rise and subsequent decline of six-rayed discoasters having large central areas between 11.4 and $11.8 \mathrm{Ma}$, there occupying over $46 \%$, on average, of the total Discoaster assemblage;

(4) the rapid rise and subsequent large oscillations in abundance, from $<30 \%$ to over $60 \%$, of the five- and six-rayed discoasters having pointed ray tips; in terms of relative abundance there is a strong antiphasing relationship (R-value: -0.86 ) between this group and the $D$. variabilis group;

(5) the dominance of D. bellus between 174.16 and $186.13 \mathrm{~m}$, there occupying over $75 \%$, on average, of the total Discoaster assemblage, with peak values of $92 \%$ in two samples;

(6) five samples lack discoasters: $5.83 \mathrm{Ma} / 92.30 \mathrm{~m}, 10.36 \mathrm{Ma} /$ $218.80 \mathrm{~m}, 10.83 \mathrm{Ma} / 235.01 \mathrm{~m}, 11.38 \mathrm{Ma} / 253.69 \mathrm{~m}$ and $13.73 \mathrm{Ma} /$ $331.26 \mathrm{~m}$

The underlying reason(s) behind these traits remains unclear. Comparisons with palaeoenvironmental proxies such as carbonate content (dissolution), carbon isotopes (productivity) and oxygen isotopes (temperature) provide meagre results. Calculations of correlation coefficients (R) between discoasters and calcium carbonate contents analysed from the identical Site U1338 sample set (Lyle \& Backman 2013) show no strong relationship (Fig. 13). Despite large variations in carbonate contents, R-values vary between -0.16 to 0.36 at the species level, and the R-value is 0.25 for the sum of all discoasters (Backman et al. 2013). However, when $\mathrm{R}$-values are calculated over 5-10 samples in intervals showing low carbonate values due to carbonate dissolution, carbonate content is strongly and positively correlated with low abundances of discoasters.

R-values have been calculated also between partly published (Reghellin et al. 2015) and partly unpublished stable isotope (C, O) data from bulk sediment and Discoaster abundances at the species level, as well as between these stable isotopes and the sum of all discoasters. Stable isotope and Discoaster data are derived from the identical sample set. There are surprisingly low R-values between carbon and oxygen isotopes of bulk sediments on the one hand and abundances of discoasters on the other. R-values for oxygen isotope correlations range from 0.32 to -0.17 , with an average of 0.10 . The sum of all discoasters shows an R-value of 0.05 relative to oxygen isotopes. Carbon isotopes show R-values ranging from 0.09 to -0.27 , with an average of -0.10 . The sum of all discoasters shows an R-value of -0.07 relative to carbon isotopes. If the $\delta^{18} \mathrm{O}$ variations are interpreted as chiefly reflecting temperature in the photic zone environment (as the isotopes mainly represent 


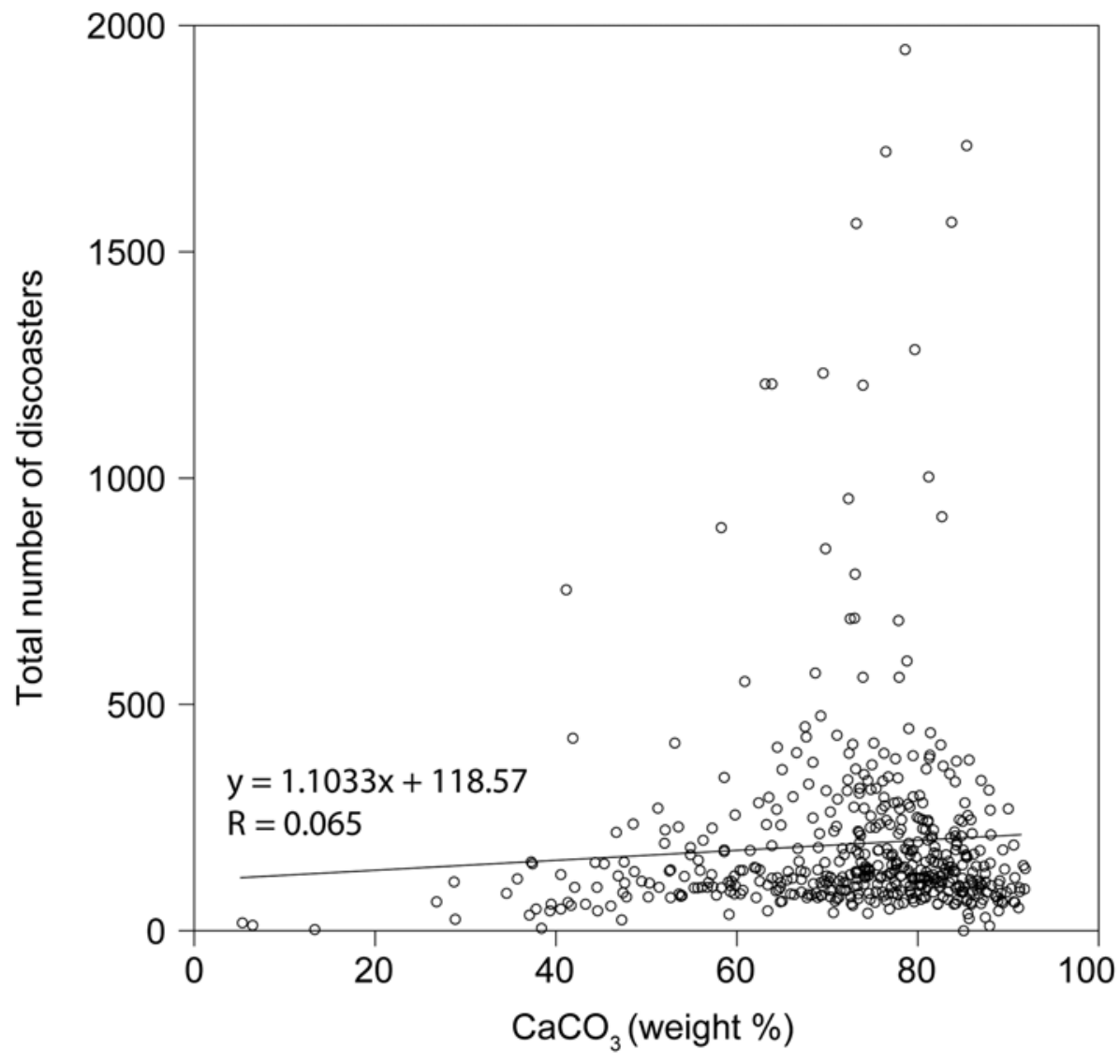

Fig. 13. Plot revealing the poor correlation between total Discoaster abundance $\left(n \mathrm{~mm}^{-2}\right)$ and carbonate content $(\mathrm{wt} \%)$ at Site U1338. All points over 440 specimens represent $D$. bellus. nannofossil carbonate; Reghellin et al. 2015), the variations in photic zone temperature at Site U1338 had no discernable effect on discoaster abundances. Similarly, if $\delta^{13} \mathrm{C}$ is interpreted as a measure of the intensity of primary productivity in the photic zone environment, the variations in productivity conditions at Site
U1338 had no discernable effect on discoaster abundances. The poor correlation between carbon and oxygen isotopes on the one hand and Discoaster abundances on the other is illustrated in Figure 14, using the bulk sediment stable isotope data of Reghellin et al. (2015).
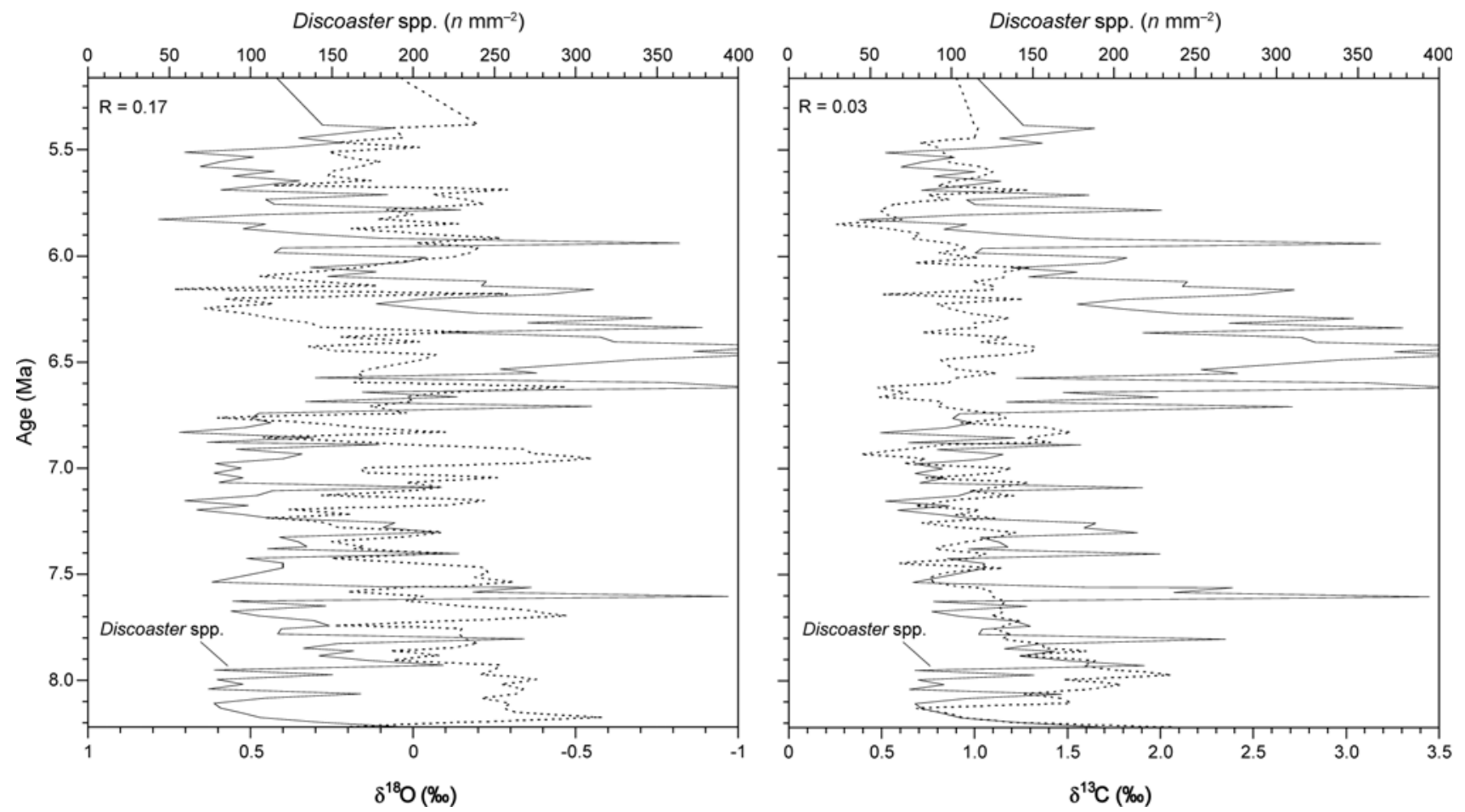

Fig. 14. Plot revealing the poor correlation between total Discoaster abundance $\left(n \mathrm{~mm}^{-2}\right)$ and oxygen isotopes (left panel) and carbon isotopes (right panel). Dotted line represents isotope data (Reghellin et al. 2015). 
Table 1. Comparison between sampling resolution used in this study, Chepstow-Lusty et al. (1989, 1992) and Gibbs et al. (2004)

\begin{tabular}{|c|c|c|c|}
\hline & Site & $\begin{array}{l}\text { Sampling resolution } \\
(\mathrm{cm})\end{array}$ & $\begin{array}{l}\text { Sample resolution } \\
(\mathrm{ka})\end{array}$ \\
\hline This study & U1338 & 68 & c. 25 \\
\hline \multirow{5}{*}{$\begin{array}{l}\text { Chepstow-Lusty et al. } \\
\text { (1989) }\end{array}$} & 552 & 10 & c. 3 \\
\hline & 659 & 10 & c. 3 \\
\hline & 662 & 10 & c. 3 \\
\hline & 607 & 15 & c. 3 \\
\hline & 658 & 30 & c. 3 \\
\hline \multirow{3}{*}{$\begin{array}{l}\text { Chepstow-Lusty et al. } \\
\text { (1992) }\end{array}$} & 662 & 10 & 2 \\
\hline & 677 & 10 & c. 0.2 \\
\hline & 709 & 5 & c. 0.5 \\
\hline \multirow[t]{2}{*}{ Gibbs et al. (2004) } & 662 & 10 & c. 3 \\
\hline & 926 & 10 & c. 3 \\
\hline
\end{tabular}

These results are at odds with those obtained from the low latitude Atlantic Ocean (Chepstow-Lusty et al. 1989, 1992; Gibbs et al. 2004), demonstrating the influence of orbitally forced climatic variation on Pliocene Discoaster abundance data. A key difference between our and these Atlantic studies is sample resolution. In our study, sample distances are, on the average, $68 \mathrm{~cm}$, corresponding to a resolution of 1 sample $/ 25 \mathrm{ka}$ in the time domain (Table 1). It appears possible that one cause for the poor correlation between abundance and isotopic oscillations may lie in insufficient sample resolution of our dataset, although other factors may be at play.

The weak correlation between $\delta^{18} \mathrm{O}, \delta^{13} \mathrm{C}$ and discoasters abundances could also be explained considering that the isotopic values are calculated on the bulk sediment, which is representative of upper photic zone nannofossil assemblage.

Imai et al. (2015) hypothesized that discoasters were living in the lower photic zone and placoliths in the upper photic zone. Therefore, following this theory, we could supposed that the isotopic signal recorded by the bulk sediment was acquired almost completely from placoliths and not from discoasters, which Imai et al. (2015) believes living in deeper waters (lower photic zone). However, there are no concrete scientific evidence supporting the theory of discoasters being deep water dwellers and, as explained in the introduction, we believe that discoasters prefer warm waters (see also Edwards 1968; Perch-Nielsen 1972; Bukry 1973a; Haq \& Lohmann 1976). A more scientific approach to explain the 'isotopic issue' encountered in this study could be running isotopic analyses on discoaster specimens isolated from the bulk and compare the results with those obtained from both bulk and foraminifera.

Comparing our abundance data with benthic isotope data from Site U1338 (Holbourn et al. 2014) suggests that the major decline in abundance of $D$. deflandrei (c. 15.7 Ma) coincides with the onset of the middle Miocene climatic optimum, and that the extinction of this species at $13.7 \pm 0.2$ Ma coincides with extensive ice growth on Antarctica and a massive increase in opal accumulation at Site U1338 (Holbourn et al. 2014; Fig. 15). Their results suggest that climate deteriorated via Antarctic ice growth, which caused intensified upwelling and increased primary productivity in the equatorial Pacific, as manifested at Site U1338. It hence appears tenable to suggest that such a dynamic Miocene photic zone environment strongly influenced Discoaster abundances, perhaps even contributed to the well-established evolutionary succession of Miocene discoasters.

\section{Acknowledgements and Funding}

We are grateful to Giuliana Villa and Mike Styzen for helpful suggestions in the review of the manuscript. This research used samples and data provided by the Integrated Ocean Drilling Program (IODP). Financial support for data acquisition was provided by Università 'G. d'Annunzio' di Chieti-Pescara (Italy) to I Raffi (Fondo Ateneo 2013). J. Backman acknowledges support from Stockholm University and the Swedish Research Council.

Scientific editing by Emanuela Mattioli

\section{References}

Aubry, M.-P. 1984. Handbook of Cenozoic Calcareous Nannoplankton. Book 1: Orthlithae (Discoasters). Micropaleontology Press, American Museum of Natural History, New York.

Backman, J. \& Pestiaux, P. 1987. Pliocene Discoaster abundance variations, Deep Sea Drilling Project Site 606: biochronology and paleoenvironmental implications. In: Ruddiman, W.F., Kidd, R.B. \& Thomas, E. (eds) Initial Reports of the Deep Sea Drilling Project, 94. US Government Printing Office, Washington, DC, 903-910.

Backman, J. \& Shackleton, N.J. 1983. Quantitative biochronology of Pliocene and early Pleistocene calcareous nannofossils from the Atlantic, Indian and Pacific oceans. Marine Micropaleontology, 8, 141-170.

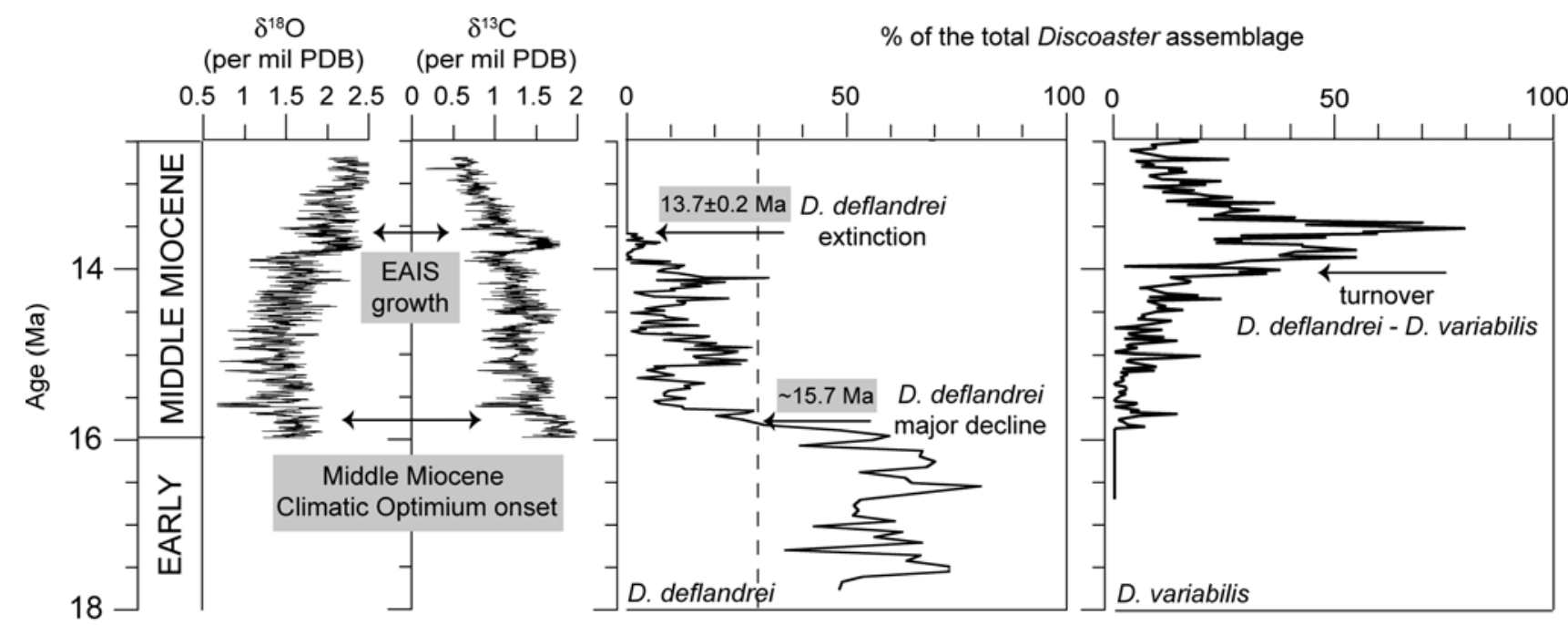

(modified from Holbourn et al., 2014)

Fig. 15. Comparison between carbon and oxygen isotope curves from Site U1338 (calculated on benthic foraminifera; Holbourn et al. 2014) and Discoaster deflandrei/Discoaster variabilis relative abundances (\%) in the middle Miocene (interval 12.5 - 16 Ma). Discoaster deflandrei major evolutionary steps (decline, extinction and turnover with Discoaster variabilis) and their link with the Mid Miocene Climatic Optimum onset and the East Antarctica Ice Sheet (EAIS) growth are indicated with arrows. All plots are v. age. 
Backman, J., Raffi, I., Rio, D., Fornaciari, E. \& Pälike, H. 2012. Biozonation and biochronology of Miocene through Pleistocene calcareous nannofossils from low and middle latitudes. Newsletters on Stratigraphy, 45, 221-244.

Backman, J., Raffi, I., Ciummelli, M. \& Baldauf, J. 2013. Species-specific responses of late Miocene Discoaster spp. to enhanced biosilica productivity in the equatorial Pacific and the Mediterranean. Geo-Marine Letters, 33, 285-298.

Backman, J., Baldauf, J.G., Ciummelli, M. \& Raffi, I. 2016. Data report: a revised biomagnetostratigraphic age model for Site U1338, IODP Expedition 320/ 321. In: Pälike, H., Lyle, M., Nishi, H., Raffi, I., Gamage, K., Klaus, A. \& the Expedition 320/321 Scientists Proceedings of the Integrated Ocean Drilling Program, 320/321. Integrated Ocean Drilling Program Management International, Tokyo, http://doi.org/10.2204/iodp.proc.320321.219.2016

Baldauf, J.G. \& Barron, J.A. 1990. Evolution of biosiliceous sedimentation patterns for the Eocene through Quaternary: Paleoceanographic response to polar cooling. In: Thiede, J. \& Bleil, U. (eds) Geologic history of the polar oceans: Arctic versus Antarctic. NATO ASI Ser. C, Kluwer, Dordrecht, 575-608.

Bown, P.R. \& Young, J.R. 1998. Techniques. In: Bown, P.R. (ed.) Calcareous Nannofossil Biostratigraphy. Kluwer Academic, Dordrecht, 16-28.

Bramlette, M.N. \& Riedel, W.R. 1954. Stratigraphic value of discoasters and some other microfossils related to Recent coccolithophores. Journal of Paleontology, 28, 385-403.

Bukry, D. 1971a. Cenozoic calcareous nannofossils from the Pacific Ocean. Transactions of the San Diego Society of Natural History, 16, 303-327.

Bukry, D. 1971b. Discoaster evolutionary trends. Micropaleontology, 17, 43-52.

Bukry, D. $1973 a$. Coccolith stratigraphy, eastern equatorial Pacific, Leg 16, Deep Sea Drilling Project. In: van Andel, T.H. \& Heath, G.R. (eds) Initial Reports of the Deep Sea Drilling Project, 16. US Government Printing Office, Washington, DC, 653-711.

Bukry, D. 1973b. Low-latitude coccolith biostratigraphic zonation. In: Edgar, N.T. \& Saunders, J.B. (eds) Initial Reports of the Deep Sea Drilling Project, 15. US Government Printing Office, Washington, DC, 685-703.

Bukry, D. 1981. Pacific coast coccolith stratigraphy between Point Conception and Cabo Corrientes, Deep Sea Drilling Project Leg 63. In: Yeats, R.S. \& Haq, B.U. (eds) Initial Reports of the Deep Sea Drilling Project, 63. US Government Printing Office, Washington, DC, 445-471.

Bukry, D. \& Percival, S.F. Jr. 1971. New Tertiary calcareous nannofossils. Tulane Studies in Geology and Paleontology, 8, 123-146.

Chepstow-Lusty, A., Backman, J. \& Shackleton, N.J. 1989. Comparison of upper Pliocene Discoaster abundance variations from North Atlantic Sites 552, 658, 659, and 662: Further evidence for marine plankton responding to orbital forcing. In: Ruddiman, W.F. \& Sarnthein, M. (eds) Proceedings of the ODP, Scientific Results, 108. Ocean Drilling Program, College Station, TX, 121-114.

Chepstow-Lusty, A., Shackleton, N.J. \& Backman, J. 1992. Upper Pliocene Discoaster abundance from the Atlantic, Pacific, and Indian oceans: the significance of productivity pressure at low latitudes. Memorie di Scienze Geologiche Padova, 44, 357-373.

Edwards, A.R. 1968. The calcareous nannoplankton for Tertiary New Zealand climates. Tuatara, 16, 26-31.

Filewicz, M.V. 1985. Calcareous nannofossil biostratigraphy of the Middle America Trench and slope, Deep Sea Drilling Project Leg 84. In: von Huene, R. \& Aubouin, J. (eds) Initial Reports of the Deep Sea Drilling Project, 84. US Government Printing Office, Washington, DC, 339-361.

Furrazzola-Bermùdez, G. \& Itturalde, V.M. 1967. Estudio micropaleontològico del Oligoceno superior de Cuba, en el pozo Pijiuàn No. 47. Tecnologica, 5, 3-11.

Gartner, S. 1967. Calcareous nannofossils from Neogene of Trinidad, Jamaica, and Gulf of Mexico. University of Kansas Paleontological Contributions, 29, 1-7.

Gibbs, S., Shackleton, N. \& Young, J. 2004. Orbitally forced climate signals in midPliocene nannofossil assemblages. Marine Micropaleontology, 51, 39-56.

Haq, B.U. \& Lohmann, G.P. 1976. Early Cenozoic calcareous nannoplankton biogeography of the Atlantic Ocean. Marine Micropaleontology, 1, 119-194.

Hay, W.W., Mohler, H.P., Roth, P.H., Schmidt, R.R. \& Boudreaux, J.E. 1967. Calcareous nannoplankton zonation of the Cenozoic of the Gulf coast and Caribbean-Antillean area and Transoceanic correlation. Transactions of the Gulf Coast Association of Geological Societies, 17, 428-459.

Holbourn, A., Kuhnt, W., Lyle, M., Schneider, L., Romero, O. \& Andersen, N. 2014. Middle Miocene climate cooling linked to intensification of eastern equatorial Pacific upwelling. Geology, 42, 19-22.

Holden, N.E., Bonardi, M.L., De Bièvre, P., Renne, P.R. \& Villa, I.M. 2011. IUPAC-IUGS common definition and convention on the use of the years as a derived unit of time (IUPAC Recommendations 2011). Pure and Applied Chemistry, 23, 1159-1162.

Imai, R., Farida, M., Sato, T. \& Iryu, Y. 2015. Evidence for eutrophication in the northwestern Pacific and eastern Indian oceans during the Miocene to Pleistocene based on the nannofossil accumulation rate, Discoaster abundance, and coccolith size distribution of Reticulofenestra. Marine Micropaleontology, 116, 15-27.

Kennett, J.P. \& Srinivasan, M.S. 1983. Neogene Planktonic Foraminifera - A Phylogenetic Atlas. Hutchington Ross.

Lohmann, G.P. \& Carlson, J.J. 1981. Oceanographic significance of Pacific late Miocene calcareous nannoplankton. Marine Micropaleontology, 6, 553-579.

Lourens, L.J., Hilgen, F.J., Shackleton, N.J., Laskar, J. \& Wilson, D. 2004. The Neogene Period. In: Gradstein, F.M., Ogg, J.G. \& Smith, A.G. (eds) A Geological Time Scale 2004. Cambridge University Press, Cambridge, 409-440.

Lyle, M. \& Backman, J. 2013. Data Report: Calibration of XRF-estimated $\mathrm{CaCO}_{3}$ along the Site U1338 splice. In: Pälike, H., Lyle, M., Nishi, H., Raffi, I.,
Gamage, K. \& Klaus, A. (eds) Proceedings of the Integrated Ocean Drilling Program, 320/321. Integrated Ocean Drilling Program Management International, Tokyo, 1-16, http://doi.org/10.2204/iodp.proc.320321.205.2013

Martini, E. \& Bramlette, M.N. 1963. Calcareous nannoplankton from the experimental mohole drilling. Journal of Paleontology, 37, 845-856.

Moore, T.C., Backman, J., Raffi, I., Nigrini, C., Sanfilippo, A., Pälike, H. \& Lyle, M. 2004. Paleogene tropical Pacific: Clues to circulation, productivity and plate motion. Paleoceanography, 19(PA3013), 1-16.

Moshkovitz, S. \& Ehrlich, A. 1980. Distribution of the cal- careous nannofossils in the Neogene sequence of the Jaf- fa-1 Borehole, Central Coastal Plain. Geological Survey of Israel Report, PD/1/80, 1-25.

Okada, H. \& Bukry, D. 1980. Supplementary modification and introduction of code numbers to the low-latitude coccolith biostratigraphic zonation (Bukry, 1973; 1975). Marine Micropaleontology, 5, 321-325.

Pälike, H., Lyle, M., Nishi, H., Raffi, I., Gamage, K. \& Klaus, A. 2010. Pacific equatorial age transect. Proceedings of the Integrated Ocean Drilling Program, 320/321. Integrated Ocean Drilling Program Management International, Tokyo, http://doi.org/10.2204/iodp.proc.320321.2010

Pennington, J.T., Mahoney, K.L., Kuwahara, V.S., Kolber, D.D., Calienes, R. \& Chavez, F.P. 2006. Primary production in the eastern tropical Pacific: A review. Progress in Oceanography, 69, 285-317.

Perch-Nielsen, K. 1972. Remarks on late Cretaceous to Pleistocene coccoliths from the North Atlantic. In: Laughton, A.S. \& Berggren, W.A. (eds) Initial Reports of the Deep Sea Drilling Project, 12. US Government Printing Office, Washington, DC, 1003-1069.

Perch-Nielsen, K. 1985. Cenozoic calcareous nannofossils. In: Bolli, H.M., Saunders, J.B. \& Perch Nielsen, K. (eds) Plankton Stratigraphy. Cambridge University Press, Cambridge, 427-554.

Prins, B. 1971. Speculations on relations, evolution, and stratigraphic distribution of discoasters. In: Farinacci, A. (ed.) Proceedings of the II Planktonic Conference. Edizion Tecnoscienza, Roma, 1017-1037.

Raffi, I. \& Flores, J.A. 1995. Pleistocene through Miocene calcareous nannofossils from Eastern Equatorial Pacific Ocean (Leg 138). In: Pisias, N.G. Mayer, L.A., Janecek, T.R., Palmer-Julson, A. \& van Andel, T.H. (eds) Proceedings of the ODP, Scientific Results, 138. Ocean Drilling Program, College Station, TX, 233-286.

Raffi, I., Rio, D., d'Atri, A., Fornaciari, E. \& Rocchetti, S. 1995. Quantitative distribution patterns and biomagnetostratigraphy of middle and late Miocene calcareous nannofossils from equatorial Indian and Pacific oceans (Legs 115, 130, and 138). In: Pisias, N.G., Mayer, L.A., Janecek, T.R., Palmer-Julson, A. \& van Andel, T.H. (eds) Proceedings of the ODP, Scientific Results, 138. Ocean Drilling Program, College Station, TX, 479-502.

Raffi, I., Backman, J. \& Rio, D. 1998. Evolutionary trends of tropical calcareous nannofossils in the late Neogene. Marine Micropaleontology, 35, 17-41.

Raffi, I., Backman, J., Fornaciari, E., Pälike, H., Rio, D., Lourens, L. \& Hilgen, F. 2006. A review of calcareous nannofossil astrobiochronology encompassing the past 25 million years. Quaternary Science Reviews, 25, 3113-3137.

Reghellin, D., Coxall, H.K., Dickens, G.R. \& Backman, J. 2015. Carbon and oxygen isotopes of bulk carbonate in sediment deposited beneath the eastern equatorial Pacific over the last 8 million years. Paleoceanography, 30, 1261-1286, http://doi.org/10.1002/2015PA002825

Rio, D., Fornaciari, E. \& Raffi, I. 1990. Late Oligocene through early Pleistocene calcareous nannofossils from western equatorial Indian Ocean (Leg 115). In Duncan, R.A., Backman, J. \& Peterson L.C. (eds) Proceedings of the ODP Scientific Results, 115. Ocean Drilling Program, College Station, TX, 175-235.

Roth, P.H. \& Thierstein, H. 1972. Calcareous nannoplankton: Leg 14 of the Deep Sea Drilling Project. In: Hayes, D.E. \& Pimm, A.C. (eds) Initial Reports of the Deep Sea Drilling Project, 14. US Government Printing Office, Washington, DC, 421-485.

Stradner, H. 1959. First report on the discoasters of the Tertiary of Austria and their stratigraphic use. In: Proceedings of the 5th World Petroleum Congress, New York, 1081-1095

Stradner, H. 1973. Catalogue of calcareous nannoplankton from sediments of Neogene age in the eastern North Atlantic and Mediterranean Sea. In: Ryan, W.B.F. \& Hsü, K.J. (eds) Initial Reports of the Deep Sea Drilling Project, 13. US Government Printing Office, Washington, DC, 1137-1199.

Takayama, T. 1969. Discoasters from the Lamont Core V21-98 (preliminary reports of the Philippine sea cores. Part 2). Bulletin of the National Science Museum, 12, 431-450

Theodoridis, S. 1984. Calcareous nannofossil biozonation of the Miocene and revision of the helicoliths and discoasters. Utrecht Micropalaeontological Bulletin, 32, 1-271.

Wei, W. \& Wise, S.W. Jr. 1990. Biogeographic gradients of middle EoceneOligocene calcareous nannoplankton in the South Atlantic Ocean Palaeogeography Palaeoclimatology Palaeoecology, 79, 29-61.

Wilkens, R.H., Dickens, G.R., Tian, J. \& Backman, J. \& Expedition 320/321 Scientists 2013. Data report: revised composite depth scales for Sites U1336, U1337, and U1338. In: Pälike, H., Lyle, M., Nishi, H., Raffi, I., Gamage, K. \& Klaus, A. (eds) Proceedings of the Integrated Ocean Drilling Program, 320/ 321. Integrated Ocean Drilling Program Management International, Tokyo, $1-158$.

Young, J.R. 1998. Neogene. In: Bown, P.R. (ed.) Calcareous Nannofossil Biostratigraphy. Kluwer Academic, Dordrecht, 225-265.

Zachos, J.C., Pagani, M., Sloan, L., Thomas, E. \& Billups, K. 2001. Trends, rhythms, and aberrations in global climate $65 \mathrm{Ma}$ to present. Science, 292, 686-693. 